\title{
DEMONIOS MÁS BIEN VISTOS QUE ESPAÑOLES. GUERRA, CATOLICISMO Y DIPLOMACIA HISPÁNICA EN LA GRAN BRETAÑA DE JACOBO I ESTUARDO (1603-1625) ${ }^{1}$
}

\author{
POR \\ Óscar AlFredo Ruiz Fernández* \\ Universidad Técnica de Construcción de Bucarest (Rumanía). \\ oaruizfernandez@gmail.com
}

\begin{abstract}
RESUMEN
Entre los años 1605 y 1625, durante la paz entre la Monarquía Hispánica y la Gran Bretaña de Jacobo Estuardo, se produjeron diferentes incidentes y enfrentamientos navales en las costas y puertos británicos entre galeones hispánicos y holandeses. Ello ocasionó siempre incidentes diplomáticos porque tanto los embajadores españoles como los holandeses presionaron a las autoridades inglesas, neutrales, para inclinarse o no en la ayuda a alguno de ambos contendientes. Ello dejaba en evidencia la falta de colaboración de la Corona inglesa en el cumplimiento de las cláusulas del tratado de paz de 1604 que la obligaban a ello ante la Monarquía. Por su parte, los soldados y tripulaciones hispánicas de esos navíos sufrieron todo tipo de penurias en un país nominalmente neutral, pero de hecho anti-español y pro-holandés por causas religiosas, políticas y económicas. Muy pocos, aparte de la propia embajada, se aventuraron a socorrer a estos hombres.
\end{abstract}

PALABRAS CLAVE: Siglo XVII; Gran Bretaña; Monarquía Hispánica; guerra naval; diplomacia; catolicismo.

\section{DEMONIOS MÁS BIEN VISTOS QUE ESPAÑOLES. SPANISH WARFARE, CATHOLICISM AND DIPLOMACY IN THE STUART GREAT BRITAIN (1603-1625)}

\begin{abstract}
During 1605 and 1625, in the years of the peace between the Spanish Monarchy and Great Britain under James I Stuart, there were several combats off the coasts and ports of Great Britain between Spanish galleons and Dutch ships. These combats always provoked diplomatic issues and disputes at the English Court among the Spanish and Dutch ambassadors. That showed the English government reluctance to comply with the treaty of 1604 with Spain, which settled the assistance of Spanish ships at British coasts and ports. Both of them were seeking the English support on their side on the occasion of these naval combats. As far as the situation of the officials and crew of these Spanish galleons, they suffered the hatred of the local protestant population, who supported the Dutch for religious, political and also economical reasons. Only a few dared to help these galleons on the British soil.
\end{abstract}

KEY WORDS: XVII century; Stuart Great Britain; Spanish Monarchy; naval warfare; diplomacy; catholicism.

$\begin{array}{ll}\text { Recibido/Received } & 19-03-2013 \\ \text { Aceptado/Accepted } & 11-04-2014\end{array}$

\section{INTRODUCCIÓN}

La consecución de la paz entre la Monarquía Hispánica e Inglaterra en agosto de 1604 (tratado de Londres) resultó

* Este artículo está realizado en el marco del proyecto nacional de investigación "Grupos de Poder, Comunidades e individuos del Norte de Europa en la Monarquía Hispánica durante la edad Moderna. Integración y diversidad". Ministerio de Economía y Competitividad (Dirección General de Investigación Científica y Técnica - Subdirección General de Proyectos de Investigación). HAR2012-36884-C02-01.

1 Expresión utilizada por el embajador español en Inglaterra, ser un factor clave en el ulterior desarrollo de la guerra de Flandes (1568-1648) y las primeras fases de la Guerra de los Treinta Años (1618-1648). El fin de la ayuda inglesa a Holanda trajo evidentes beneficios para la ofensiva española por tierra y mar contra Holanda, especialmente destacados entre los años 1603-1607 y 1621-1625, así como la consecución de la Tregua de los Doce Años en 1609; además,

don Carlos Coloma, para explicar el odio escocés a España; Archivo General de Simancas (en adelante, AGS), Estado, 8789, 68. Don Carlos Coloma al marqués de los Balbases. Londres, 19 de febrero de 1623. 
la neutralidad inglesa en los años 1618-1625 facilitó enormemente la crucial intervención española en Alemania en favor del emperador. ${ }^{2}$ En cuanto a la amenaza holandesa sobre las posesiones españolas en las Indias Occidentales y Orientales, la Monarquía Hispánica tenía ahora puestos en ambos lados del Canal de la Mancha para poder vigilar y amenazar a los navíos y flotas rebeldes. Además, desde Flandes y también desde Inglaterra se podría actuar conjuntamente contra el comercio y las pesquerías holandesas, base de la economía de las Provincias Unidas. Un buen ejemplo de esta coordinación lo tenemos en la persona de don Carlos Coloma, maestre de campo en Flandes, defensor a ultranza de la guerra naval contra Holanda y embajador en Inglaterra. ${ }^{3}$ Una simbiosis perfecta de soldado (en Flandes) y embajador (en Inglaterra). Él mismo se calificaba de "caballo de entrambas sillas, según me solía llamar el señor Don Baltasar [de Zúñiga]". ${ }^{4}$

En lo relativo al comercio marítimo, los artículos nueve y diez establecían nuevamente el libre comercio entre Inglaterra y los territorios europeos de la Monarquía. En concreto, el punto nueve declaraba "Entre el rey de Inglaterra y el de España....sea libre el comercio". ${ }^{5}$ Por su parte, el número diez se ocupaba de la entrada y visita de los navíos de guerra en los puertos de uno y otro reino, "ora llegando forzados de tormenta o de su voluntad para reparar las naves o comprar bastimentos" ${ }^{6}$ En principio se permitía su entrada, salvo si su número excedía de seis u ocho, en cuyo caso se necesitaría el permiso expreso del soberano respectivo para su acogida (bien Jacobo I, bien Felipe III). Este

2 Estas ideas están plenamente aceptadas hoy día por la Historiografía, por lo que eludo citas bibliográficas extensas; en referencia a las ventajas de la diplomacia para la Monarquía, en 1623, tras el regreso del príncipe de Gales a Inglaterra sin esposa española, los ingleses comentaban que "los españoles con los tratados ganan más que con las guerras"; sir Charles Cornwallis, embajador inglés en España, escribía en 1605 que la paz con Inglaterra había permitido a los españoles "concentrarse en Holanda y dar [...] aliento y tiempo [a la Monarquía]": (AGS), Estado, 841, 9 (Villamediana al Condestable, marzo de 1604); 842, 162 (Condestable al rey, agosto de 1604); Biblioteca Palacio Rea (en adelante, BP), II/2590, 16 (Coloma a Ciriza, octubre de 1623); Allen, P.C. 2001. Felipe III y la Pax Hispánica: 78-81: Madrid: Alianza; Thompson, I.A.A. 2005. "Sir Charles Cornwallis y su Discurso sobre el Estado de España (1608)", en P. Sanz Camañes (ed.), La Monarquía His pánica en Tiempos del Quijote: 65-101. Madrid: Editorial Silex; sobre la guerra de los Treinta Años y la intervención española, ver Parker, G. (ed.) 2004. La guerra de los Treinta Años, Madrid: Antonio Machado; Elliott, J. H. 1998. El conde-duque de Olivares. El político en una época de decadencia, Barcelona: Mondadori; Brightwell, P. 1974. "The Spanish system and the twelve years's truce, English Historical Review, 89: 270-292; Feros, A. 2002. El duque de Lerma. Realeza y privanza en la España de Felipe III, Madrid: Marcial Pons.

Coloma escribió un memorial defendiendo la guerra marítima contra los holandeses en 1621, y lo volvió a enviar a la Infanta Isabel en 1623; Archivo Histórico Nacional (en adelante, AHN), Estado, 741, 52-57. Papel que hizo don Carlos Coloma en razón de como se debe continuar la guerra con holandeses y que haciéndosela vivamente en su casa dejarán lo que tienen fuera. De la posada, 15 de febrero de 1621; AGS, Estado, 8792, 68. Don Carlos Coloma a la Infanta Isabel Clara Eugenia. Londres, 29 de diciembre de 1623.

4 AGS, Estado, 8788, 106. Don Carlos Coloma a Antonio de Aróstegui. Londres, 11 de noviembre de 1622.

AHN, Estado, 2798, 6. Capitulaciones de la Paz hecha entre el Rey Nuestro Señor, archiduques (señores de Flandes) y el rey de Gran Bretaña (rey de Inglaterra, Escocia e Irlanda). Londres 28 de agosto de 1604.

6 Ibídem. artículo, en lo referente a los navíos de guerra, sería origen y foco de numerosos conflictos a tres bandas entre las autoridades británicas, la Monarquía y el gobierno holandés, ya que la neutralidad inglesa después de casi veinte años de guerra contra España (1585-1603) sacó a relucir las contradicciones entre un tratado que restablecía la amistad entre los dos países y la enemistad declarada de la mayoría de la población inglesa, que veía con disgusto como su soberano ayudaba a combatir a sus tradicionales aliados holandeses. ${ }^{7}$

Por lo que respecto al resto de artículos del tratado hasta el vigésimo, se centran esencialmente en asegurarse la no colaboración inglesa en el contrabando holandés, así como desactivación del llamado Decreto Gauna o del 30\% para los comerciantes británicos. ${ }^{8}$ Este decreto de guerra económica, sucesor de los embargos de navíos, bienes y mercancías ejecutados contra los enemigos de la Monarquía de los años 1585, 1598 y 1601, fue una de las primeras condiciones presentadas por los ingleses para el establecimiento de la paz con la Monarquía. ${ }^{9}$ La Monarquía tuvo que dejarlo sin efecto con respecto a Inglaterra y Francia en 1604, y con Holanda a partir de $1607 . .^{10}$

Para la embajada española en Inglaterra socorrer a los galeones hispánicos llegados a los puertos y costas británicas sería una de sus tareas fundamentales, y también representaría una seria preocupación hasta 1625 (año del reinicio de nuevas hostilidades entre ambos estados y de la salida del último diplomático hispánico de Inglaterra). ${ }^{11}$ Por su parte, para la mayoría de oficiales, soldados y tripulaciones de esos navíos, la estancia en las costas y puertos de

El capítulo catorce de la obra del jurista Alberico Gentili, Hispanicae Advocationis Libri Duo (1613) trataba de los casos en los que barcos holandeses atacaban y bloqueaban a navíos españoles en puertos y costas británicas: "Whether the King may rightfully decide that Spaniards who have been roughly handled by the Dutch off a port of the King may sail in safety to Belgium); Gentili, jurista protestante de origen italiano, se convirtió en un famoso profesor de Derecho en la universidad de Oxford y trabajó para el gobierno inglés en cuestiones de Derecho internacional (por ejemplo, fue consultado sobre qué hacer tras descubrirse la implicación del embajador español don Bernardino de Mendoza en la conspiración de Francis Throckmorton; finalmente fue expulsado en de Inglaterra en 1584); desde 1603 estuvo a sueldo de la embajada española como jurista; para ver más sobre Gentili, Van der Molen, G. 1968. Alberico Gentili and the Development of International Law. Leyden; para la relación intelectual Gentili-Grocio, Kingsbury, B. 2000. "Gentili, Grotius and the extra-european world", en H.N. Scheiber (ed.), The Law of the Sea: 39-60. The Hague.

8 Biblioteca Nacional de Madrid (en adelante, BNM), mss 1492, 117-122, Proposición del medio que dio Juan de Gauna para quitar a los rebeldes el comercio reduciendolo a las provincias obedentes y acabar la guerra. Gante 1602. Juan Lopez de Ugarte; mss 2347, 61-65, Capitulaciones para el comercio con los extranjeros. Valladolid 27 de febrero de 1603. Para ver más sobre el Decreto Gauna, ver Echevarría Bacigalupe, M.A.1998. Flandes y la Monarquía Hispánica, 1500-1713, Madrid; Alloza Aparicio, M.A. 2012 “Guerra económica y proteccionismo en la Europa del siglo XVII: el decreto Gauna a la luz de los documentos contables". Tiempos Modernos, 24: 1-34.

9 AGS, Estado, 840, 262. Conde de Villamediana a Su Majestad, Southampton, 1 de octubre de 1603.

10 Archivo Casa Ducal de Alba (en adelante, ADA), leg. 21, 2. Concordia sobre la revocación del decreto Gauna del 30\% entre España, Francia y Flandes hecho por octubre de 1604, dado en Valladolid el 12 de noviembre de 1604 y pregonado en Valladolid el domingo 21 de noviembre de 1604.

11 El agente flamenco Jacques Bruneau fue el último representante diplomático de Felipe IV en permanecer en Inglaterra, entre octubre de 1624 y diciembre de 1625. 
Gran Bretaña supondría en general una experiencia terrible que conllevaría penalidades, sufrimientos y muertes, muy alejada de lo que se podría esperar en un país neutral y oficialmente amigo de la Monarquía Hispánica.

Los estudiosos de la Historia Militar de la Edad Moderna han dedicado algunas páginas brillantes a estos combates navales entre ingleses, holandeses e ingleses en aguas atlánticas y nórdicas. Algunas de ellas han querido poner en evidencia la fortaleza española en el mar, como las de Cesáreo Fernández Duro. ${ }^{12}$ Finalmente, la historiografía se ha orientado hacia la profundización en el esfuerzo español por responder al desafío mundial que representaban las emergentes potencias navales: Inglaterra, Holanda y posteriormente Francia. La guerra ha dejado de estudiarse como una mera sucesión de combates. Estos historiadores se han aproximado a los conflictos entre españoles, ingleses y holandeses desde una perspectiva global que unificaba los aspectos militares, religiosos, diplomáticos, comerciales y políticos, tal y como la guerra se entendía desde mediados del siglo xvı. La economía, la política y la guerra como un todo inseparable. ${ }^{13}$

Posteriormente, otros historiadores españoles han continuado profundizando en esta vía de investigación, como Porfirio Sanz Camañes, J.E. Gelabert o Bernardo García García. ${ }^{14}$ Por su parte, los historiadores anglosajones no se han quedado atrás, con los clásicos de J.H. Elliot sobre Olivares, G. Parker, R.A. Stradling, I.A.A. Thompson, J. Israel, Sabek y Deng o David Goodman (El poderío naval español. Historia de la armada española del siglo XVII). ${ }^{15}$

Este artículo pretende continuar en esa línea historiográfica, centrando la atención en las experiencias directas documentadas de soldados, mercaderes y diplomáticos hispánicos en la Inglaterra de los Estuardo, y reflejando como la política, la diplomacia, la religión y el comercio influyeron

12 En la monumental obra de Duro Historia de la Armada española desde la unión de Castilla y de Aragón, 1895-1903, la conclusión global era que en un juicio global, la Armada española había ganado la «batalla del Atlántico» (y del Pacífico y Mediterráneo) hasta el desastre de Trafalgar en 1805.

13 Ejemplo de ello fueron las obras de Alcalá-Zamora y Queipo de Llano, España, Flandes y el Mar del Norte (1618-1639), de 1975; Margarita Pi Corrales, La otra Invencible, 1574: España y las potencias nórdicas, de 1983; y Gómez-Centurión, Felipe II, la empresa de Inglaterra y el comercio septentrional (1566-1609), de 1988.

14 Porfirio Sanz Camañes, Diplomacia hispano-inglesa en el siglo xVII. Razón de Estado y Relaciones de Poder durante la Guerra de los Treinta años, 1618-1648; Los ecos de la Armada. España, Inglaterra y la estabilidad del Norte (1585-1660), J.E. Gelabert, Guerra y coyuntura fiscal: el embargo general de 1598; Ángel Alloza Aparicio, Europa en el mercado español. Mercaderes, represalias y contrabando en el siglo XVII; o Bernardo García García, La Pax Hispánica. Política exterior del duque de Lerma.

15 G. Parker, La gran estrategia de Felipe II; El ejército de Flandes y el Camino Español 1567-1659; España y los Países Bajos 1559-1659; R.A. Stradling, Europa y el declive de la estructura imperial española 1580-1720; La armada de Flandes. Política naval española y guerra europea, 1568-1668; I.A.A. Thompson, Guerra y decadencia. Gobierno y administración en la España de los Austrias (1560-1620); "La guerra y el soldado", en Antonio Feros y Juan Gelabert (eds.), España en tiempos del Quijote; J. Israel, Empires and entrepots: the Dutch, the Spanish monarchy and the Jews, 1585-1713; The Dutch Republic. Its rise, greatness and fall 1477-1806; o David Goodman, El poderío naval español. Historia de la armada española del siglo XVII; Sabek y S. Deng, Global traffic: discourses and practices of trade in English literature and culture from 1550 to 1700 . en la vida de tantos hombres que sirvieron a la Monarquía Hispánica en el norte de Europa.

Entre los años 1600 y 1605 tuvieron lugar al menos cinco importantes enfrentamientos entre navíos flamencos y holandeses ante las costas y puertos británicos; en agosto de 1600 (en aguas del Canal de la Mancha), en diciembre de 1604 (en la isla de Wight y Porstmouth), y en junio (Dover), noviembre (Canal de la Mancha) y en diciembre de $1605 .{ }^{16}$ Durante los años de la Tregua de los Doce Años (1609-1621), destacan dos casos en los cuales la embajada proporcionó ayuda y amparo, uno acaecido en marzo de 1616, cuando el galeón San Alberto, al mando del almirante don Diego de Brochero, tuvo que tomar refugio en Plymouth víctima de una tormenta; otro en enero de 1617, cuando una carabela de la armada española al mando del capitán Diego Iñiguez de Anderica llegó a Plymouth sin aparejos y bastimentos tras sufrir otro temporal. ${ }^{17} \mathrm{~A}$ partir de 1621 , con la reanudación de la guerra contra los holandeses, la embajada española en Inglaterra se vio envuelta entre los años 1622-1623 en el auxilio a dos galeones flamencos refugiados en puertos escoceses; en 1624 hubo de acudir en ayuda de los navíos del maestre de campo don Diego de Oliveira, refugiados en Dover, y de nuevo en junio de 1625 el agente flamenco Jacques Bruneau intervino en el incidente del galeón Santa Clara, cuya tripulación y oficiales, unos 60 hombres, fue apresada por las autoridades inglesas en Dover. ${ }^{18}$

Con la paz de la Monarquía Hispánica con Inglaterra, los holandeses perdieron a su mejor aliado, que además vigilaba sus espaldas en el Canal de la Mancha. A partir de 1603 la opción que les quedaba era extremar la vigilancia sobre las aguas del Canal para evitar el transporte de tropas a Flandes desde Inglaterra o la Península Ibérica. ${ }^{19}$ Ello provocaría continuos roces, tensiones y enfrentamientos con Inglaterra entre los años 1603-1607 y entre 1621-1625, pero era algo inevitable si los holandeses querían continuar la lucha contra la Monarquía Hispánica. ${ }^{20}$ Un informe español de 1605 afirmaba que frente a los puertos flamencos de

16 BNM, ms. 2759, 109-136. Discurso de las fuerzas de mar que tienen los holandeses y en qué consisten. 1605.

17 Sobre el almirante don Diego Brochero, ver Williams, P. 2001. “Don Diego de Brochero de Paz y Anaya (c. 1535-1625). Corsario, almirante y administrador". Cuadernos Monográficos del Instituto de Historia y Cultura Naval 37: 7-14 y Guell Junkert, M. 2004. “Diego Brochero, el lobo de mar salmantino". Revista de Historia Naval, 87: 95104; BNM, 2348, 489-490. Relación de don Diego Brochero al conde de Gondomar sobre el viaje de su armada de Lisboa a Flandes. 15 de abril de 1616; (BP), II/1829, 42-43. Su Majestad al conde de Gondomar. Madrid, 26 de mayo de 1617.

18 Sobre los casos de los años $1622-1623$ y 1624, citados más adelante; sobre el de 1625, British Library (en adelante, BL), Harleian Mss, 1583, 368-369. Jacques Bruneau a Su Majestad el Serenísimo Rey de la Gran Bretaña. Chelsea, 7 de septiembre de 1625.

19 El transporte por mar entre 1600 y 1625 se hizo en los años 1601, 1602, 1605, 1611, 1615, 1620 y 1623: en BNM, ms. 17659, s/f. Consulta del consejo de Estado sobre el embarque de levas por mar a Flandes. Madrid, 8 de octubre de 1622; Parker, G. 2000. El ejército de Flandes y el Camino español, 1567-1659: 324 Madrid.

20 En 1624 el conde Mauricio de Nassau dejaba claro el dilema holandés ante las protestas inglesas por el bloqueo de Dover donde estaban refugiados varios navíos hispánicos afirmando que "no podía establecer ninguna diferencia entre la satisfacción de las demandas de Su Majestad el rey Jacobo I y la ruina de su Estado": Stradling, R.A. 1992. La armada de Flandes. Política naval española y guerra europea, 1568-1668: 69-77 Madrid. 
Ostende, Niewpoort, Dunkerque y Gravelinas los holandeses tenían posicionados veinticinco navíos, y entre Dover y Calais patrullaban otros ocho, siempre dispuestos a aumentar de número (hasta ochenta) si alguna armada española se atrevía a embocar el Canal de la Mancha. Mantener todo este complejo sistema de vigilancia y patrulla del Canal de la Mancha y costas flamencas suponía a Holanda 99.000 florines mensuales (36.000 ducados), una cifra similar al coste de la armada de Flandes para la Monarquía. ${ }^{21}$

Parece claro que en la vertiente marítima de la guerra de Flandes se daban episodios de barbarie y salvajismo aún mayores que en los combates terrestres (si es que ello era posible). A los riesgos de los combates se añadían las epidemias (escorbuto), las tormentas, los incendios, el hambre (agua y alimentos en mal estado) y las malas condiciones de vida a bordo de los navíos, con lo que las bajas en los combates navales eran superiores a las de la guerra terrestre..$^{22}$ Además los documentos y cartas de esos años dan noticias de crueldades sin cuento en los combates entre navíos holandeses e hispánicos. Las ejecuciones de prisioneros eran muy frecuentes. Los ahorcamientos de tripulaciones rendidas eran habituales (puesto que se las consideraba corsarias), así como las ejecuciones a palos, los lanzamientos por la borda, y todo tipo de vejaciones. Las razones para ello, aparte de la dificultad de trasladar a los prisioneros hasta puertos seguros, quizá estuvieran en el origen de las tripulaciones, flamencas y holandesas, con una lengua y cultura comunes pero separadas por el odio político y religioso, lo que añadía un carácter de guerra civil al conflicto. Además, para Holanda, el mar era su medio de supervivencia, constantemente amenazado por los navíos de la Monarquía. Esto no parecía ocurrir en la guerra terrestre, al menos desde 1599, cuando se habilitaron sistemas de canje general de prisioneros entre holandeses y españoles. ${ }^{23}$

\section{El tercio de don Pedro SARMiento (1605)}

Ante la interceptación de barcos ingleses de camino a Flandes en aguas del Canal de la Mancha a lo largo de la

21 Los gastos de mantenimiento de la armada de Flandes, compuesta por entre 15 y 20 navíos, oscilaban entre los 20.000 y 30.000 ducados mensuales: Stradling, R.A. 1992: 48 y 255-260; BNM, ms. 2759, 109-136. Discurso de las fuerzas de mar que tienen los holandeses y en qué consisten. 1605; AHN, Estado, 52-57, Papel que hizo don Carlos Coloma en razón de como se debe continuar la guerra con holandeses y que haciéndosela vivamente en su casa dejarán lo que tienen fuera. De la posada, 15 de febrero de 1621.

22 Stradling, R.A. 1992: 205-208.

23 Un informe relataba varias crueldades cometidas por los holandeses contra tripulaciones flamencas; entre ellas, de cómo en junio de 1605, tras un combate en el Canal, un oficial flamenco del galeón rendido había escapado tirándose por la borda y los holandeses le habían perseguido con chalupas hasta matarlo a picazos y estocadas para después decapitarle; el embajador don Carlos Coloma informó en 1623 que un muchacho al que había enviado a servir a Flandes contaba que "los españoles [eran] echados al mar por holandeses que ataban balas de cañón a las partes vergonzosas"; es posible que en estas crueldades influyera también la práctica de quemar y volar los navíos que estaban a punto de rendirse, para evitar ser tomados por el enemigo e intentar hundir los barcos que estuvieran más próximos: BNM, ms. 2759, 109-136. Discurso de las fuerzas de mar que tienen los holandeses y en qué consisten. 1605; AGS, Estado, 8792, 46. Don Carlos Coloma al marqués de los Balbases. Londres, 27 de octubre de 1623; Parker, G. 2000: 37-38, 140 y 169-170. primavera de 1605, las protestas del embajador español, conde de Villamediana, habían resultado vanas puesto que las autoridades inglesas se lavaban las manos. El rey Jacobo declaró que el tratado de paz sólo le obligaba a intentar "persuadir" a los holandeses a que no bloquearan el Canal de la Mancha, pero no a utilizar la fuerza o las amenazas contra ellos; además, se rechazó la propuesta española de transportar a los reclutas británicos para el ejercito de Flandes en navíos del rey inglés. ${ }^{24} \mathrm{Y}$ con esto llegó la primera prueba seria de la recientemente estrenada amistad hispano-inglesa. Un grupo de ocho navíos ingleses y escoceses fueron alquilados en la primavera de 1605 para transportar 1.200 soldados españoles, irlandeses e italianos del Tercio del maestre de campo don Pedro Sarmiento desde Lisboa a Dunkerque. ${ }^{25}$ Interceptados por una escuadra holandesa cerca de Dover el 14 de junio, se inició un violento combate en el que cuatro navíos ingleses fueron quemados. ${ }^{26}$ Los cuatro navíos supervivientes se refugiaron en Dover, donde fueron cañoneados por los holandeses desde la misma bocana del puerto. Sólo la intervención de la artillería del castillo de Dover evitó la destrucción de los navíos refugiados. ${ }^{27}$

Se planteaba ahora el dilema de qué hacer con los 600 soldados acantonados allí. El 16 de julio el maestre Sarmiento escribía a Felipe III informándole de los problemas que tenía por la falta de ayuda inglesa. ${ }^{28} \mathrm{Al}$ parecer no recibió ninguna facilidad de las autoridades. ${ }^{29}$ Pidiendo alojamiento para las tropas, se le habían ofrecido en una ocasión tres lugares distintos y en otra trasladarlos a Canterbury. En ambos casos el maestre se negó porque temía que sus tropas se disgregaran en pequeños grupos incontrolados, que cayeran fácilmente en la mendicidad y el crimen, perdiéndose completamente en Inglaterra y deshaciéndose como fuerza de combate. Por ello, Sarmiento informaba que "mientras no

24 Calendar of State Papers (CSP), Venice, (1603-1607), Nicolo Molin, embajador veneciano en Inglaterra, al Dogo y Senado. Londres 18 de mayo/15 de junio/27 de julio de 1605; Loomie, A.J. 1996. Spain and the Early Stuarts, 1585-1655: 32-33 Aldershot.

25 Los navíos en ruta hacia Flandes tocaron el puerto de La Coruña, donde Lord Howard había avisado de que el Canal estaba vigilado por 80 navíos holandeses; aunque los habían contratado para llevarlos a la costa inglesa, se pretendía desembarcarlos en Dunkerque: CSP, Venice, (1603-1607). Nicolo Molin, embajador veneciano en Inglaterra, al Dogo y Senado. Londres 29 de junio de 1605.

26 La llegada del convoy era conocida por los holandeses, y en Londres y París era algo que se sospechaba (los embajadores venecianos informaron de ello): CSP, Venice, (1603-1607), Nicolo Molin, embajador veneciano en Inglaterra, al Dogo y Senado. Londres 18 de mayo de 1605; Anzolo Badoer, embajador veneciano en Francia, al Dogo y al Senado. París 24 de mayo de 1605.

27 En cuanto a los supervivientes, el almirante holandés Haultain ató de dos en dos a algunos de los soldados prisioneros y los tiró por la borda, mientras otros acabaron siendo enviados presos a Holanda, como el caso de dos capitanes y 40 soldados; estas crueldades en el mar debían ser bastante habituales: Loomie, A.J.1996: 32-33; Allen, P.C. 2001: 212-213.

28 AGS, Estado, 840, 50.Consulta del consejo de Estado sobre lo que el maestre de campo don Pedro Sarmiento escribe a Vuestra Majestad en carta de 16 de julio de 1605 en materias de Inglaterra y embarcación y pasaje de su gente a los estados de Flandes. Valladolid, 6 de septiembre de 1605.

${ }_{29}$ De hecho, el maestre subrayaba que "la acogida que ha hallado allí no fue tan buena como se pensó acá por muchas cosas porque aquellos holandeses sólo tratan de decir mal dellos y darles malas nuevas de sus cosas": Ídem. 
tuviere otra orden por escrito del embajador [don Pedro de Zúñiga] no sacará bandera ni hombre de aquellos navíos". ${ }^{30}$ Felipe III ordenó que se escribieran cartas para Jacobo y Lord Charles Howard, y que de parte de los embajadores Zúñiga y Villamediana solicitaran permiso para embarcar a todos los soldados en navíos del rey de Inglaterra para tener pasaje seguro a Flandes "pues esta comodidad no es ofender a los rebeldes de las islas ni ir contra la neutralidad, sino corresponder a la amistad y hermandad que tiene [el rey de Inglaterra] con Vuestra Majestad, que en ocasión semejante hiciera lo mismo". 31

Por su parte, los embajadores hicieron todo lo posible para ayudar a estos soldados. Don Pedro de Zúñiga gastó 223.083 reales en ayuda a los soldados entre los meses de julio y diciembre de 1605 , los cuales estaban en una penosa situación:

"de la gente que se escapó de los dichos navíos esta mucha della desnuda y ha escrito al Señor archiduque suplicándole mandase si tuviesen hechos algunos vestidos para cuando lleguen allí y así mismo se hallan desarmados y que ha escrito al embajador para que le provea de algunas armas y que procura licencia para enviárselas". ${ }^{32}$

La asistencia se materializó en pagos en metálico por parte de los mercaderes genoveses Juan Francisco Soprani y Felipe Bernardi a oficiales del Tercio, "que por orden del maestre de campo venían cada vez diferentes oficiales en secreto porque no fuesen conocidos respecto del riesgo tan grande que había de serlo y que les robasen el dinero y otras veces que lo envié con criados míos al dicho puerto [de Dover]. ${ }^{33}$ Además, se rescató a los soldados supervivientes que habían sido tomados prisioneros y llevados a Holanda y se recuperó la artillería y mosquetes que se habían dejado en depósito en Dover. Según las cuentas de Zúñiga, el 17 de diciembre de 1605 se pagaron 70 reales a un marino español que había venido en el navío que había traído a los soldados presos de Holanda. Y se pagaron 800 reales en dos veces (21 de octubre y 17 de noviembre de 1605) a Luisa Saven, esposa de Juan Saven, un inglés que viajaba en alguno de los ocho navíos del convoy de soldados y que también fue llevado preso. ${ }^{34}$ Con respecto a las armas, el 10 de julio de 1609 el embajador pagó 100 reales por obtener del consejo de Estado inglés las órdenes para que el Mayor de Dover (alcalde) entregara la artillería y mosquetes que allí habían quedado desde 1605. El 23 de julio se pagaron 980 reales al alcalde por el depósito de estas armas, y 150 reales más se dieron al licenciado Francis Fowler, secretario de lenguas del embajador, por ir a Dover a entregarlo todo al alférez Padilla, enviado por el marqués Ambrosio Spínola.

${ }_{31}$ Ídem.

32 El dinero fue remitido por el archiduque Alberto mediante letras de Francisco Serra en Amberes a cobrar en Londres: AGS, Tribunal Mayor de Cuentas, 2633. Relación jurada y cuentas de don Pedro de Zúñiga, marqués de Floresdávila. Data de gastos de maravedies hechos en el entretenimiento de la infantería española del tercio del Maestre de Campo don Pedro Sarmiento que arribó a Inglaterra.

33 ídem.

34 La embajada también se ocupó de pagar a los huérfanos y viudas de unos escoceses que murieron en los combates: BL, Cotton Vespasian (CV), 64. Don Pedro de Zúñiga a sir Charles Cornwallis. Londres, 11 de diciembre de 1607.
En cuanto al pasaje de los soldados, el asunto se convirtió en un embrollo diplomático entre Inglaterra, la Monarquía y Holanda. La petición española de que la tropa pasara a Flandes chocó con la oposición de la mayoría del consejo de Estado inglés, que argüía que eso era violar su neutralidad. ${ }^{35}$ Además, el agente holandés en Inglaterra, el caballero Noel Carón, argumentaba que permitir aquello era una declaración de abierta hostilidad contra Holanda, que ellos nunca habían dado motivos para semejante trato, y que si barcos holandeses encontraran soldados de la Monarquía a bordo de navíos ingleses, atacarían sin dudarlo. La respuesta final de Jacobo fue amonestar a los embajadores españoles por usar barcos escoceses e ingleses para transportar tropas a Flandes sabiendo que él quería mantenerse neutral. ${ }^{36}$ El soberano inglés subrayaba que esos barcos habían sido contratados para viajar a Inglaterra, lo cual era un acto sospechoso y hostil porque era llevar tropas extranjeras a su reino sin su conocimiento previo. Además, él no se sentía en la obligación de asegurar el paso de tales tropas porque ofendería a los holandeses, y mucho menos que cruzaran el Canal de la Mancha en sus propios navíos. A lo único que se prestaba era a mediar para que esos soldados regresaran a España.

Quedaba claro a los embajadores que no había nada que esperar de los ingleses, por lo que sólo se podía aguardar e intentar pasar a los soldados bajo apariencia de pasajeros y mercaderes en los navíos mercantes que cruzaban el Canal, aunque este medio permitía pasar pocos soldados y a mucho coste para la embajada. ${ }^{37}$ Pese a la indignación mostrada por Villamediana y su insistencia durante los meses de agosto y septiembre, el rey no cedió, y los soldados siguieron esperando en Dover. A finales de diciembre pudieron cruzar hacia Flandes en pequeñas barcas, al abrigo de las largas noches invernales y el mal tiempo. ${ }^{38}$ Fue gracias al

35 Sólo una minoría de los consejeros defendía que Jacobo debía hacer honor a una de las cláusulas de la paz de 1604 respecto de "procurar dejar abierto el paso a Flandes"; el secretario Cecil, aunque aseguraba que Jacobo tampoco otorgaba ningún favor especial a los holandeses, se negaba a tomar partido contra de ellos: CSP, Venice, (1603-1607), Nicolo Molin, embajador veneciano en Inglaterra, al Dogo y Senado. Londres 29 de junio de 1605; Loomie, A.J. 1996: 32-33.

36 No sería el único caso de navíos alquilados para el transporte de tropas desde España a Flandes; en septiembre de 1615, una armada de 18 navíos al mando de don Diego Brochero llevó 42 compañías de infantería de Lisboa a Dunkerque; de los 18, cuatro eran barcos del rey y catorce eran extranjeros; en 1639, muchos navíos de transporte en la armada de don Antonio de Oquendo también serían británicos: BNM, ms. 2348, 489-490. Relación de don Diego Brochero a don Diego Sarmiento de Acuña sobre el viaje de su armada de Lisboa a Flandes. 15 de abril de 1616.

37 CSP, Venice, (1603-1607). Nicolo Molin, embajador veneciano en Inglaterra, al Dogo y Senado. Londres 13 de julio de 1605.

38 En 1625, el ejército de Mansfeld cruzó así de Dover a Calais, "que no dista más de siete leguas de travesía, y que toda esta gente se pasaba en navíos pequeños de franceses e ingleses que no servían más que para estos pasajes"; durante la batalla de las Dunas (1639), los soldados que transportaban los galeones españoles cruzaron de la misma forma: CSP, Venice, (1603-1607). Nicolo Molin, embajador veneciano en Inglaterra al Dogo y al Senado. Londres 28 de septiembre de 1605; AHN, Estado, 737, 492-494. Consulta del consejo de Estado sobre una consulta inclusa del consejo de Portugal y dos relaciones que se han tenido de las armadas que en Holanda e Inglaterra se preparaban. Madrid 14 de marzo de 1625; Alcalá-Zamora y Queipo de Llano, J. 1975. España, Flandes y el Mar del Norte: 443-445 Barcelona. 
doctor Robert Taylor, entretenido del embajador Zúñiga, como se consiguió que finalmente las tropas pudieran salir de Dover hacia Flandes y no retornaran a España. ${ }^{39}$

\section{GALEONES FLAMENCOS EN ESCOCIA (1622-1623).}

Entre junio de 1622 y agosto de 1623, dos galeones de la armada de Flandes, el San Ambrosio y el Nuestra Señora de Begoña, se refugiaron en los puertos escoceses de Leith y Aberdeen tras intensos combates con navíos holandeses. La primera mención sobre ello aparece en una carta del embajador español don Carlos Coloma al rey Felipe IV con fecha de 16 de junio de 1622. Dos navíos de Ostende se habían visto inmersos en varios combates con los holandeses, y habían hundido quince barcos cargados de trigo, bacalao y madera que venían del mar Báltico. ${ }^{40} \mathrm{El}$ embajador aseguraba que tras conocer su llegada a Escocia, "les he enviado con toda diligencia algún socorro [de dinero] y cartas recomendatorias deste rey" ${ }^{41}$ Seis días después de esta carta, el embajador marqués de Bedmar desde Bruselas informaba a Coloma que unos avisos venidos de Holanda con fecha de 17 de junio confirmaban esos combates. ${ }^{42}$

El 30 de junio, el rey Jacobo fue avisado de todo el asunto por el gobernador de la villa de Leith..$^{43}$ En septiembre, el rey concedió a Coloma licencia para poder enviar municiones y bastimentos a ambos galeones, el San Ambrosio, al mando de Peter Van Nooren/Vooren en Leith y el Nuestra Señora de Begoña (Antonio Rotaeche) en Aberdeen, bloqueados por seis navíos holandeses cada uno. ${ }^{44}$ En octubre el embajador informaba de que esperaba que los galeones salieran en breve en busca de las municiones, bastimentos y marineros que les había enviado por mar desde Londres. Incluso un caballero católico escocés llamado sir Daniel McDonnell se había ofrecido a embarcar soldados en ellos a cambio de ser nombrado capitán. ${ }^{45}$

39 AGS, Estado, 841, 141. Conde de Villamediana a Su Majestad. Oxford, 14 de septiembre de 1603; 2571, 167. Su Majestad a don Pedro de Zúñiga. Valladolid, 27 de marzo de 1606; véanse las cuentas de Zúñiga.

40 En realidad, habían sido tres los navíos flamencos que habían interceptado el convoy holandés; en el transcurso de los combates, dos de ellos habían huido, mientras que el tercero, al mando de Jan Jacobsen, había hecho frente durante 13 horas a nueve navíos holandeses hasta que dinamitó su propio galeón, hundiendo otros dos enemigos: AGS, Estado, 8788, 20 y 29 (cartas de Coloma al rey y la infanta Isabel de junio y julio de 1622); Stradling, R.A. 1992: 69-77.

41 AGS, Estado, 8788, 20. Don Carlos Coloma a Su Majestad. Londres, 16 de junio de 1622 .

42 Ibídem, 8773, 18. Marqués de Bedmar a don Carlos Coloma. Bruselas, 22 de junio de 1622.

43 Ibídem, 8788, 29. Don Carlos Coloma a la infanta Isabel Clara Eugenia. Londres, 1 de julio de 1622.

44 Los barcos de las armadas reales solían recibir nombres religiosos, relacionados con el lugar de construcción o un santo; Begoña era un nombre popular entre los barcos construidos en Vizcaya; en cuanto al San Ambrosio, era un nombre que unía el santoral católico con el nombre de Ambrosio Spínola; común era también el de San Alberto, en homenaje al archiduque: AGS, Estado, 8788, 69 (Coloma al rey, septiembre de 1622) y 8789, 13 y 18 (Coloma a Spínola, enero de 1623); Rahn Phillips, C. 1991. Seis galeones para el rey de España. La defensa imperial a principios del siglo XVII: 83-123 Madrid.

45 La infanta Isabel contestó al embajador que procuraría dar satisfacción al caballero escocés: AGS, Estado, 8788, 98. Don Carlos Coloma a la infanta Isabel Clara Eugenia. Londres, 28 de octubre de 1622; 8770, 83. Infanta Isabel Clara Eugenia a don Carlos Coloma. Bruselas, 7 de noviembre de 1622 .
Es en enero de 1623 cuando en las cartas del embajador aparece por primera vez la mención de William Laing. Este personaje era un mercader católico natural de Aberdeen que, a su costa, había viajado hasta Londres para fletar un navío y socorrer a los dos galeones con bastimentos, artillería, jarcia y marineros. Los holandeses, enterados de ello, habían puesto precio a su cabeza, y se habían distribuido cien retratos suyos para asesinarle. Por su acción, el comerciante había perdido sus negocios, y temía por su vida. El embajador había pedido a Felipe IV que se le concediera un entretenimiento en la embajada por sus buenos servicios. ${ }^{46}$ Además, había estado prestando dinero al capitán Rotaeche para abastecer al galeón de Aberdeen durante siete meses, mientras que el navío de Peter Van Nooren en Leith se había sustentado con más de 600 ducados de Laing y el dinero disponible de las presas obtenidas de sus ataques corsarios. ${ }^{47}$ Por todo ello, Coloma había dado garantías de abonar todas las deudas contraídas con Laing. ${ }^{48}$

Al mes siguiente el embajador informó a Ambrosio Spínola que habían decidido sacar primero el galeón de Leith. Para ello, había enviado desde Londres un navío con 26 marineros el 16 de febrero, y por tierra letras de cambio por valor de 1.000 escudos y 400 más en crédito. ${ }^{49}$ Para el socorro del galeón de Aberdeen, había enviado a William Laing con cerca de 2.000 escudos más. ${ }^{50}$

A lo largo de la primavera de 1623, el socorro a los galeones se dificultó día a día. En Edimburgo los predicadores y la mayoría de la población simpatizaba con los holandeses, oponiéndose a que se prestase socorro y ayuda a los navíos. Coloma se quejaba reiteradas veces de la hostilidad que los escoceses mostraban a los españoles. Incluso se llegó a encarcelar a Laing, y sólo una patente firmada por Jacobo consiguió liberarlo. ${ }^{51}$ En mayo se descubrió un plan urdido por ciertos marineros ingleses para quemar el Nuestra Señora de Begoña en Aberdeen. ${ }^{52}$ Ante todas estas dificultades, el embajador consiguió finalmente que el rey Jacobo enviara dos de sus navíos para escoltar a los galeones y enfrentarse a cuantos holandeses lo impidieran. ${ }^{53}$

Desgraciadamente, si bien se abortó la conspiración en Aberdeen, no se impidió la quema del galeón San

46 Un entretenimiento de 40 escudos al mes, cobrados entre marzo de 1623 y junio de 1625, momento en el que Laing se exilió a Flandes: AGS, Estado, 8789, 9. Don Carlos Coloma a Su Majestad. Londres, 6 de enero de 1623; 8781, 4. Su Majestad a don Carlos Coloma. Madrid, 2 de marzo de 1623; AHN, Estado, 800, s/f. Servicios de Guillermo Laing; Alcalá-Zamora y Queipo de Llano, J. 1975: 203-204.

47 William Laing prestó entre junio de 1622 y enero de 1623 unos 3.200 ducados al capitán Rotaeche en Aberdeen: AGS, Estado, 8789, 13 y 18 (Coloma a Spínola, enero de 1623).

48 ídem.

49 AGS, Estado, 8789, 83. Don Carlos Coloma al marqués de los Balbases. Londres, 24 de febrero de 1623.

50 Por entonces, Jacobo había transmitido una propuesta holandesa: si el capitán Van Nooren liberaba ciertos prisioneros holandeses, los navíos que le bloqueaban en Leith le concederían dos mareas de tiempo para escapar a mar abierto; Ídem.

51 Decía que en Escocia los demonios eran mejor vistos que los españoles, y que los escoceses eran "bestias y fieras más inhumanas que tigres contra católicos": AGS, Estado, 8789, 68 y 84 (Coloma a Spínola y a Mateo Urquina, febrero de 1623).

52 Ibídem, 8791, 2 y 6 (Coloma al cardenal de la Cueva y a Spínola, mayo de 1623).

53 Ídem. 
Ambrosio en Leith. ${ }^{54}$ Al parecer, el incendio del navío fue un plan holandés con participación de varios escoceses..$^{55}$ Semejante acción en un puerto británico supuestamente neutral indignó a Coloma, que fue "bramando a este rey [...] deseaba saber quién era el rey de la Gran Bretaña, él o los holandeses [...] les había de ver un día emprender otras cosas, donde se interesase por ventura la salud de su persona, y sucesión de su hijo". ${ }^{56}$ Ante la gravedad del asunto, Jacobo reunió al consejo Privado, prometiendo castigar severamente a los culpables y sacar al otro galeón con ayuda de dos navíos ingleses para (junto con los despojos y la tripulación del San Ambrosio, que en total sumaban 200 hombres), llevarlo todo al puerto flamenco de Mardick. ${ }^{57}$

El embajador, harto de las conspiraciones, retrasos y otras excusas, recomendaba que los capitanes de los barcos del rey que deberían tener por verdad absoluta que "por ningún caso de los mundo entren en puertos de Escocia, ni Inglaterra [navíos de Su Majestad] porque creo firmemente que no saldrán de ellos jamás [...] todo lo demás es lisonjearnos a nosotros mismos; esto suplico quede asentado por máxima". 58

En cuanto al coste del socorro a los dos galeones, en febrero de 1623 el veedor de la Armada de Flandes (Vicente de Anciondo) y el pagador general del Ejército de Flandes (Tomás de Mendieta) enviaron 20.000 florines. En junio de 1623 Coloma informaba de que como los gastos se concentraban en el galeón de Aberdeen (Nuestra Señora de Begoña), y a la tripulación del galeón quemado (San Ambrosio) se la había tenido que dar dos pagas, promesa de una tercera y más garantías de pago y pasaportes, enviaba al Veedor de la Armada una cuenta de otros 9.086 florines. ${ }^{59}$

54 Si bien se quemó el galeón, la carga, artillería y tripulación se salvaron: AGS, Estado, 8791, 31. Don Carlos Coloma a Juan de Ciriza. Londres, 22 de mayo de 1623.

55 El galeón estaba amarrado a los baluartes del puerto, por lo que el incendio sólo pudo provocarse con la colaboración de gentes del lugar; para más humillación, el navío estaba bajo el amparo de los estandartes reales de Jacobo: Ibídem, 34. Don Carlos Coloma a Juan de Ciriza. Londres, 24 de mayo de 1623; 8782, 18 y 19 (Coloma a Spínola, junio de 1623).

56 Tras la quema del galeón en Leith, Juan Bautista Van Male había propuesto que varios navíos flamencos fueran directamente a Aberdeen a sacar por la fuerza al otro barco bloqueado: AGS, Estado, 8791, 35. Don Carlos Coloma al marqués de los Balbases. Londres, 25 de mayo de 1623; 8792, 18. Marqués de los Balbases a don Carlos Coloma. Bruselas, 1 de junio de 1623.

57 Coloma escribía que el incendio "se ha tomado mal tanto entre herejes como entre católicos, y en la reunión del consejo de Estado sobre ello nuestros enemigos hablaron de forma que cuando lo supe entendí se había de declarar la guerra a esos rebeldes [...] creía que los escoceses se disculparían por lo ocurrido como en Fuenteovejuna": AGS, Estado, 8791, 24,35, 39 y 52 (Coloma a Juan de Ciriza, Spínola y Laing, mayo y junio de 1623).

58 En esto había cambiado de idea respecto de un año antes, cuando advertía a la Infanta Isabel que había que tratar bien a los comerciantes escoceses "cuyos puertos es fuerza que frecuenten nuestros bajeles"; en 1623 escribía que "para mí no hay diferencia ninguna dellos [los puertos escoceses] a los de Holanda, sino que allá los matan [a los marineros y destruyen los galeones] de una vez y acá de muchas: AGS, Estado, 8788, 99. Don Carlos Coloma a la Infanta Isabel Clara Eugenia. Londres, 28 de octubre de 1622; 8791, 47, 51 y 52 (Coloma a la Infanta, a Spínola y al cardenal de la Cueva, junio de 1623).

59 A los 20.000 florines iniciales (12.500 por el veedor y 7.500 por el pagador), y los 8.560 florines de junio de 1623 , se añadirían otros 2.000 escudos hasta finales de agosto de 1623 (una partida de 1.200
Por último, a finales de agosto remitió una última cuenta de 2.000 escudos al veedor. Los gastos de catorce meses habían supuesto 136.344 reales (algo más de 34.000 florines, unos 13.634,4 escudos).

Por fin, el 11 de julio salieron del puerto de Las Dunas los dos navíos ingleses que habrían de escoltar al galeón flamenco hacia Mardick. ${ }^{60}$ En agosto de 1623 Coloma informaba a Felipe IV de la odisea del galeón superviviente. La salida del navío del puerto de Aberdeen no presentó dificultades (pese a que había cinco navíos holandeses vigilando), y tampoco la carga de la artillería del San Ambrosio en Leith. Pero parece que una vez en alta mar, y cuando los dos navíos ingleses estaban a seis millas del galeón, este fue atacado por los holandeses, muriendo el capitán Rotaeche, el piloto, seis marineros y echando abajo el palo mayor. Por ello, los navíos ingleses escoltaron al galeón hasta Las Dunas, donde mantuvieron a raya a los holandeses. Quedaba entonces el galeón al mando del contramaestre y reparándose allí. ${ }^{61} \mathrm{Sin}$ embargo, Jacobo ordenaría su ida al puerto de Gravesend por seguridad (a donde fue Coloma a pagar a la tripulación todo lo que se les debía), desde donde partieron con su escolta el 25 de agosto hacia Mardick, a donde arribó sin problemas. ${ }^{62}$

\section{Galeones de don Diego LUIS de Oliveira (1624)}

El último incidente a destacar ocurrió durante los meses de mayo a julio de 1624, cuando cuatro galeones flamencos se refugiaron en Dover después de haber combatido contra los holandeses (la embajada gastó en su auxilio 8.323 reales). El 19 de mayo, seis galeones al mando del maestre de campo portugués don Diego Luis de Oliveira, partieron de Mardick rumbo a San Sebastián. ${ }^{63}$ Uno de ellos encalló en los arenales de la costa flamenca, y los otros cinco hicieron frente a unos 20 navíos holandeses. Tras 18 horas de combate, uno de los barcos se hundía, y los otros buscaron refugio en las Dunas. El 20 de mayo, Oliveira enviaba al sargento Ausias Rodríguez a informar a los embajadores Hinojosa y Coloma de todo, así como para pedir "pólvora y algunas balas de mosquete y escribe que convendrá si fuese posible encaminar que abrigados aquellos bajeles por alguno deste

y otra de 800 al $5 \%$ de interés); los 9.086 florines ( 8.560 más cambios e intereses) y los 2.000 escudos últimos se remitirín a pagar al veedor y al pagador general: Ibídem, 8782, 5. Marqués de los Balbases a don Carlos Coloma. Bruselas, 15 de febrero de 1623; 8791,15, 48 y 64 (Coloma a Spínola y Pedro de San Juan, junio, julio y agosto de 1623); 8792, 5 (Spínola a Coloma, febrero de 1623).

60 Ibídem, 8791, 64. Don Carlos Coloma al marqués de los Balbases. Londres, 11 de julio de 1623.

61 Los cinco navíos holandeses regresaron a Vlissingen, donde desembarcaron a más de $\mathbf{3 0}$ marineros muertos durante el combate en Las Dunas "para irritar y conmover al pueblo contra los ingleses": Ibídem, 8792, 12 y 13 (Coloma al rey, agosto de 1623).

62 En una carta del 12 de octubre, Spínola felicitaba al embajador porque el galeón estaba a salvo en Mardick y aprestándose para salir a la mar a combatir; la infanta Isabel haría lo propio: Ibídem, 8782, 28. Marqués de los Balbases a don Carlos Coloma. Bruselas, 12 de octubre de 1623; 8787, 36; 8787, 36. Infanta Isabel Clara Eugenia a don Carlos Coloma. Bruselas, 11 de octubre de 1623; 8792, 13, 15 y 30 (Coloma al rey, a Pedro de San Juan y a Spínola, agosto y septiembre de 1623).

63 BNM, ms. 10467, 274-275. Marqués de la Hinojosa a Su Majestad. Londres, 4 de junio de 1624; Alcalá-Zamora y Queipo de Llano, J. 1975: 204-205; Stradling, R.A. 1992: 69-77. 
rey o del que yo tenga que usar para pasar el canal, vuelvan a Mardick". ${ }^{64}$ Hinojosa haría todo lo posible para socorrer a los galeones, aunque obtener una escolta inglesa hasta Mardick lo veía muy difícil dada la situación política en Inglaterra, por lo que creía que era mejor salir del bloqueo cuando hubiera un tiempo revuelto en la mar. Cuatro días después se dieron 6.000 reales a Juan Bautista Van Male para municionar a los navíos. ${ }^{65}$ Además, los embajadores avisaron al secretario de Estado sir Edward Conway, pero al no obtener respuesta, se dirigieron por carta a Jacobo solicitando su protección a los navíos como así se explicitaba en los capítulos de la paz de $1604 .{ }^{66}$ La respuesta inglesa fue que se dispondría de la salida de los galeones, o bien dándoles dos mareas de ventaja respecto de los holandeses o bien escoltándoles. Sin embargo, Hinojosa se enteró que el consejo Privado había decidido embargar 50 piezas de artillería "de que se hizo presa en un navío que yendo de aquí a Holanda tomaron las fragatas de Ostende porque dicen que eran inglesas". ${ }^{67}$ Esto era, a juicio del embajador, dejar a los galeones flamencos sin artillería y a merced holandesa.

El rumbo de las cosas ya se mostraba similar a casos anteriores, pues los ingleses ponían trabas y mil dificultades para el socorro de los navíos. Hinojosa escribía a Felipe IV que era el Parlamento el que presionaba a Jacobo para no facilitar la salida de los galeones de Dover. ${ }^{68}$ Además, el embajador relataba todas las maniobras que los ministros ingleses estaban haciendo para entorpecer el abastecimiento de los galeones: negaban el permiso para socorrerlos, embargaron la pólvora enviada, retuvieron en Dover pertrechos enviados desde Dunkerque y además el príncipe de Gales había ordenado decir "a las justicias de los lugares vecinos de la [costa] marina y este río [Támesis] que se tenía por servido que no se nos vendiese nada, con que se prueba que todas sus acciones se encaminan a ocasionar la guerra".69

Como a finales de junio la salida de los galeones no progresaba, los embajadores intentaron sobornar a Conway, "aunque holandés por él, y tan mal afecto a Vuestra Majestad, muestra como los demás destas partes que su ley se ajusta con sus intereses"..$^{70}$ Le ofrecieron 12.000 ducados

"porque tomase por su cuenta la salida de los galeones de donde se encuentra [...] y cuando no se consiga estamos don Carlos Coloma y yo en decir a este rey que

64 Ibídem, 260. Marqués de la Hinojosa a la Infanta Isabel Clara Eugenia. Londres, 20 de mayo de 1624.

65 Ibídem, 261. Marqués de la Hinojosa a la Infanta Isabel Clara Eugenia. Londres, 24 de mayo de 1624.

${ }_{66}$ Ibídem, 262. Marqués de la Hinojosa al Serenísimo Rey de Gran Bretaña. Londres, 28 de mayo de 1624.

67 BNM, ms. 10467, 263-264. Marqués de la Hinojosa a la Infanta Isabel Clara Eugenia. Londres, 30 de mayo de 1624.

68 Ibídem, 274-275. Marqués de la Hinojosa a Su Majestad. Londres, 4 de junio de 1624.

69 Ibídem, 276-281. Marqués de la Hinojosa a Su Majestad. Londres, 13 de junio de 1624.

70 Coloma se lamentaba de "estos pobres navíos de don Diego Luis [de Oliveira] antes muertos que nacidos, me lastiman viéndolos ya casi desahuciados y sujetos a morir de hambre cuando les falte a estos perros [ingleses] otro género de muerte que darles: Ibídem, 290-291. Marqués de la Hinojosa a Su Majestad. Londres, 20 de junio de 1624 Archivo de la Casa de Alba (ADA), 233, 24. Don Carlos Coloma al cardenal de la Cueva. Londres, 21 de junio de 1624. se encargue de los navíos y los tome para hacer después dellos lo que le pareciere y que ponga la gente en Mardick supuesto que donde se encuentran están tan expuestos a que los holandeses que los tienen rodeados de 18 navíos suyos los hagan pedazos y se pierda la infantería y marinería, que ésta causaría tanta falta según nos dice el veedor Vicente Anciondo, que se encontraría imposibilitado Vuestra Majestad de suplirla en mucho tiempo". ${ }^{71}$

Al parecer, la causa de los retrasos estaba en el príncipe de Gales. Pese a la orden expresa de Jacobo a principios de junio, el secretario Conway fue dilatándola por orden del heredero hasta el día 24 de junio. ${ }^{72}$ Obtenida la orden, Hinojosa preparó su salida de Inglaterra, mientras Coloma esperaba que "si ellos son cuerdos y me creen [los oficiales de los galeones], caiga el que cayere, se saldrán de donde están con el primer temporal del norte o nordeste, y [...] se pondrán esos galeones en seis horas en MardicK". ${ }^{73}$

A principios de julio, Oliveira abandonaba los galeones y cruzaba el Canal de la Mancha junto con el marqués de la Hinojosa (embajador extraordinario en Inglaterra que regresaba a Madrid) para dirigirse primero a Flandes y luego a España. ${ }^{74}$ Mientras, la salida de los galeones seguía demorándose a mediados de mes, así que el 18 de julio, en otro encuentro de Coloma y Conway, el secretario vino a dejar claro que la cuestión no era simplemente los galeones, sino que

"a los holandeses conviene sustentarlos a precio de nuestra sangre [inglesa] y de la de todos los reyes de Europa, porque caídos una vez en vuestras manos, con el oro de vuestras Indias, quien habría que se atreviese a pensar en otra cosa que en obedeceros y besar el azote [español]". ${ }^{75}$

La neutralidad inglesa en la guerra de Flandes no podía ocultar el hecho de que a Inglaterra (como a Francia, Venecia, Saboya o a los protestantes alemanes) no le convenía la victoria final española. Facilitar el socorro a soldados y navíos que llegaran a sus costas sólo podía ir en una dirección, explicitada por el conde Mauricio de Nassau en su respuesta a las quejas del rey Jacobo por el bloqueo de sus puertos "no podía establecer ninguna diferencia entre la satisfacción a las demandas de Su Majestad y la ruina de su Estado [...] pues en ese caso, los Estados [de las Provincias

71 En total los cuatro galeones llevaban 1.000 hombres.

72 Felipe IV aprobó el ofrecimiento del dinero para obtener la salida de sus galeones el 8 de julio de 1624: BNM, ms. 10467, 295-297. Marqués de la Hinojosa a Su Majestad. Londres, 26 de junio de 1624; AGS, Estado, 2516, 83. Consulta de Estado sobre los despachos de Inglaterra desde 4 de mayo a 20 de junio de 1624 y desde Paris de 19 y 25 de junio (marqués de Mirabel). Madrid, 8 de julio de 1624.

73 ADA, 233, 24. Don Carlos Coloma al cardenal de la Cueva. Londres, 28 de junio de 1624.

${ }_{74}$ El día 5 de julio desembarcaba en Calais, y el 4 de agosto se encontraba en París con el marqués de Mirabel; a finales de agosto estaba ya en Madrid esperando órdenes; sería enviado de nuevo a Flandes y luego a Las Dunas a salir con sus galeones: BNM, ms. 10467, 300. Marqués de la Hinojosa a Su Majestad. Calais, 5 de julio de 1624; ms. 18428, 104. Cristóbal Lope Floriano [secretario del marqués de Mirabel] al conde de Gondomar. Paris 23 de agosto de 1624; AGS, Estado, 2516, 91. Consulta del consejo de Estado sobre cartas de don Carlos Coloma de 19 de julio a 9 de agosto. Madrid, 30 de agosto de 1624.

75 ADA, 233, 24. Don Carlos Coloma al cardenal de la Cueva. Londres, 19 de julio de 1624 . 
Unidas] deberían cesar la guerra, ya que España tendría una ruta suficiente para su armada. ${ }^{76}$

En Madrid se había consultado a don Fadrique de Toledo su posible ida a Las Dunas en rescate de los galeones, a lo que se había opuesto por el mal estado de los 24 navíos que harían falta para la operación. ${ }^{77}$ Esta decisión sería muy lamentada por Coloma, que la consideraba como una falta de firmeza ante las provocaciones inglesas:

"yo en este lenguaje he hablado y hablo en España y cierto no como soldado sino como embajador, no sé en qué se piensan ni qué razón hay para disculpar el no haber enviado acá una muy gentil escuadra de galeones con que sacar de la esclavitud a estos pobres galeones sitiados en las Dunas, pues desde el primer día dimos a este por único remedio, y viven muy engañados [en España] si piensan que este [remedio] había de ser causa para romper la guerra [con Inglaterra] que no lo fuera cierto sino la [causa] más urgente y encaminada a conservar la paz [con los ingleses] supuesto que nada sin el miedo basta para tener a raya a esta gente bárbara y vil". ${ }^{78}$

A finales de julio por fin las cosas parecían clarificarse: Van Male escribía que los galeones habían recibido las anclas enviadas desde Dunkerque, y se esperaba por horas la llegada de la orden para meter las municiones. ${ }^{79}$ El día 28 de julio enviaría a Dover 24 barriles de pólvora y plomo para balas de mosquete, con que confiaba en que se harían a la mar a la primera oportunidad. Sin embargo, en Madrid no lo entendían así, ya que lamentaban la ausencia de Oliveira, que había ocasionado el retraso en la salida de los navíos. ${ }^{80}$ Además, Felipe IV ordenó que el secretario Andrés de Prada fuera a quejarse al embajador inglés sir Walter Aston por la contravención de la paz en el socorro de los galeones. EI secretario presentó las reclamaciones españolas

"por la poca asistencia que han tenido los cuatro navíos de Dunquerque que se acogieron en el puerto de Dunas

76 BNM, ms. 9393, 191-192. Respuesta de los Estados Generales de las Provincias Unidas a los embajadores de Inglaterra conde de Arundel, caballero Amstruder, embajador de Su Majestad y el residente Boswell. La Haya, 31 de enero de 1633; Stradling, R.A. 1992: 69-77.

77 Se pensaba en una expedición como la de octubre de 1622, cuando don Fadrique de Toledo dirigió una armada de 22 navíos hasta la entrada del Canal de la Mancha para interceptar las flotas holandesas; la carta de don Fadrique rechazando el plan era de 11 de julio: AGS, Estado, 2516, 90. Consulta del consejo de Estado sobre lo que se ofrece en el socorro de los 4 navíos de Dunquerque que están en las Dunas (como Vuestra Majestad lo mandó) con ocasión de haber visto por los últimos despachos del marqués de la Hinojosa de 5 de julio de 1624 desde Calais que se trae consigo al Maestre de Campo don Luis de Oliveira que tenía a cargo estos navíos. Madrid 24 de julio de 1624

78 En Inglaterra se pensaba que se enviaría una escuadra española a liberar a los galeones, por lo que los holandeses pidieron permiso Jacobo para entrar en Las Dunas y hundirlos; Sir Francis Cottington había propuesto a Coloma que si no se pudiesen sacar los navíos, se quemaran y hundieran, salvando a los soldados y tripulantes: ADA, 233, 24. Don Carlos Coloma al cardenal de la Cueva. Londres, 26 de julio de 1624; AGS, Estado, 2516, 91. Consulta del consejo de Estado sobre cartas de don Carlos Coloma de 19 de julio a 9 de agosto. Madrid, 30 de agosto de 1624.

79 El veedor de la Armada Vicente de Anciondo también llegó a Dover a supervisar el abastecimiento de los galeones: ADA, 219, 1. Avisos de Inglaterra. Juan Bautista Van Male. Londres, 27 de julio de 1624.

80 AGS, Estado, 2516, 84. Consulta del consejo de Estado sobre despachos de Carlos Coloma desde Inglaterra de 3 a 8 de julio. Madrid, 29 de julio de 1624 . para que pudieran volverse a puertos de Su Majestad, incumpliendo las paces y el juramento que se hizo de ellas, haciendo con esos barcos lo mismo que con otro navío que fue a Escocia [el caso de los dos navíos de Aberdeen y Leith], a quien también sitiaron los rebeldes en otro puerto de ese reino". 81

Aston replicó que las paces no obligaban a Jacobo a socorrer a los galeones españoles, a lo que respondió Prada que "aunque era verdad que en las paces no ponía nada de amparo a barcos españoles en puertos ingleses y asegurar su salida, parece que la cortesía y buena correspondencia entre ambas coronas lo obligaba". ${ }^{82}$ Esta era la clave del asunto, la voluntariedad del socorro: los ingleses demostraron cuando hubo ocasión que preferían ser meros espectadores ante los combates entre holandeses y españoles en sus costas.

Un mes después, la situación era ya desesperada, pues los navíos seguían bloqueados y además los gobernadores ingleses habían prohibido abastecer a los españoles con la excusa de que "encarecían [los precios de] los bastimentos [...] ya los enfermos [de los galeones] no se les dio acogida". ${ }^{83}$ Felipe IV ordenaba que los galeones con el primer tiempo salieran hacia Mardick o hacia algún puerto de España. Así mismo, que se advirtiera al embajador sir Walter Aston que si se perdían los navíos, en España se podría ordenar "por vía de represalia en la misma cantidad y valor de los galeones, que ajustadamente se haga el arresto en las haciendas y navíos que hubiese de Inglaterra en estos reinos no comenzando la diligencia hasta estar los dichos cuatro galeones perdidos". ${ }^{44}$ Finalmente, aprovechando cuatro días de tormenta, forzaron el bloqueo para dirigirse a Mardick. Durante la travesía se enfrentaron a los holandeses, y la nave almiranta voló junto a la equivalente holandesa. Los otros tres navíos llegaron a salvo a puerto..$^{85} \mathrm{~A}$ don Diego Luís de Oliveira se le recompensaría con el cargo de gobernador y capitán general del Brasil. ${ }^{86}$

\section{SOLDADOS, MERCADERES Y EMBAJADORES}

Desde septiembre de 1603, cuando el primer embajador enviado por Felipe III pisa tierra inglesa (el conde de Villamediana, don Juan de Tassis), la embajada española

81 Ibídem, 93. Consulta de oficio del consejo de Estado. Sobre lo que el secretario don Andrés de Losada y Prada pasó con el embajador inglés acerca de la queja que se tiene de su amo por no asegurar los navíos que entraron en las Dunas. Madrid, 4 de septiembre de 1624.

82 Ídem.

$83 \mathrm{BP}, \mathrm{II} / 2220,16$. Consulta del consejo de Estado sobre algunas de don Carlos Coloma. Madrid, 19 de septiembre de 1624.

84 Ídem.

85 La tormenta tuvo lugar entre los días 13 y 18 de octubre de 1624 : BNM, ms. 2355, 217-218. Traslado de una carta en que declara todo lo sucedido en los estados de Flandes desde el fin de agosto a 20 de octubre de 1624. Y también de los 4 bajeles de Dunquerque [refugiados en las Dunas]. Por Rodrigo de Lara. Impresa en Madrid por Juan Delgado, 1624.

86 El 19 de marzo de 1625; lo ocuparía entre 1626 y 1634, cuando fue enviado a recuperar la isla de Curaçao de manos holandesas; en 1622 estuvo al cargo de la nación española durante el asedio de Bergen-op-zoom, luego sustituido por don Diego Messía, castellano de Amberes: BNM, ms. 18719, 36. Relación de servicios de don Diego Luís de Oliveira; Colección de Documentos Inéditos para la Historia de España, (CODOIN), volumen 71, Relación de la vida del capitán Domingo de Toral y Valdés, escrita por él mismo: 495-547; Alcalá-Zamora y Queipo de Llano, J. 1975: 205. 
comenzó a hacer frente a los numerosos problemas derivados del nuevo estatus de Inglaterra como potencia neutral entre la Monarquía Católica y la república de Holanda. ${ }^{87}$ Entre ellos, como se ha visto más arriba, prestar ayuda y protección a los navíos de las armadas de Su Majestad que entablaban combates a muerte con los navíos holandeses en aguas del Canal de la Mancha o del Mar del Norte. Sin embargo, los historiadores también descubrimos en los archivos no sólo la correspondencia oficial entre ministros y embajadores de Inglaterra, España y Flandes, sino también documentos acerca de aquellos directos protagonistas de las acciones que narraban los diplomáticos. Estos papeles, a veces no demasiado exhaustivos ni detallados, nos proporcionan en la medida de lo posible un testimonio de primera mano de las vivencias de todos aquellos que arriesgaron vida y hacienda en el servicio a Su Majestad.

Por una parte, los soldados y tripulaciones de los galeones de Su Majestad llegaban a puertos y costas extranjeras, se veían rodeados de una población local de religión protestante que en su mayoría los odiaba, eran maltratados por las autoridades locales y estaban expuestos a la lenta acción de la burocracia de la corte inglesa. Nadie los quería allí, no eran bienvenidos, y a lo máximo que podían aspirar era a poder obtener sustento mientras durase su bloqueo en las costas británicas por parte de los navíos holandeses. Sólo esperaban y confiaban en la acción de los embajadores de la Monarquía. Por otra, se encontraban algunos súbditos británicos que, a la búsqueda de aventura, un porvenir, un futuro más próspero sirviendo a otro príncipe (en la administración, la milicia o la armada) o por motivos religiosos, sirvieron a la Monarquía Católica, "sin otra obligación que la de su propia virtud [...] con el mismo amor y riesgo que si fuera vasallo". 88

Un informe interesante, si bien breve, es el presentado por el almirante don Diego de Brochero al embajador español en Inglaterra don Diego Sarmiento de Acuña, conde de Gondomar. ${ }^{89}$ Fue elaborado en la primavera de 1616, y relata brevemente el viaje de dieciocho navíos, desde Lisboa a Dunkerque, transportando cuarenta y dos compañías de soldados de infantería para el ejército de Flandes. Nada especial, pues la ruta marítima para el envío de tropas entre España y Flandes se utilizaba como alternativa al llamado "Camino español", y además en esos años estaba vigente la Tregua con los holandeses, con lo cual no había ningún peligro para esos convoyes..$^{90}$ Sin embargo, los navíos tenían

87 Relación muy verdadera del recibimiento y fiestas que se le hicieron en Inglaterra a don Juan de Tassis, conde de Villamediana, embajador extraordinario de Su Majestad del Rey don Felipe III nuestro Señor, para el nuevo Rey Jacobo de Inglaterra. Dase cuenta de la embajada y otras cosas muy notables y dignas de saberse. Impresor Bartolomé Gómez. Sevilla, 1603.

88 Estos hombres eran de origen inglés, irlandés o escocés, y pertenecían a todos los estamentos sociales, desde marineros a mercaderes, desde caballeros y soldados a grandes aristócratas: AGS, Estado, 8790, 46. Don Carlos Coloma a la Infanta Isabel Clara Eugenia. Londres, 7 de abril de 1623; para ver más sobre los servidores extranjeros de la Monarquía, Carnicer, C. y Marcos, J. 2005: Espías de Felipe II. Los servicios secretos del Imperio español. Madrid.

89 BNM, ms. 2348, 489-490. Relación de don Diego de Brochero al conde de Gondomar sobre el viaje de su armada de Lisboa a Flandes. 15 de abril de 1616 .

90 Como se ha comentado anteriormente, el transporte de tropas hispánicas desde la Península Ibérica a Flandes por mar entre 1600 y 1625 se realizó en los años 1601, 1602, 1605, 1611, 1615, 1620 y 1623. que seguir haciendo frente a otro tipo de peligros, como las tormentas, muy frecuentes en el Canal de la Mancha y mar del Norte. ${ }^{91}$ Por ello, aparecen numerosas referencias a las tormentas en la documentación de la embajada española en Inglaterra. ${ }^{92}$ Según esta relación, la escuadra salió de Lisboa en septiembre de 1615, y tras veintiocho días de viaje por mar, llegaron al puerto de Dunkerque en octubre; sólo se perdió un navío a la entrada del puerto, posiblemente por los abundantes arenales de las costas flamencas. ${ }^{93}$ Allí esperaron hasta el inicio de la primavera para retornar a Lisboa, tratando de evitar las tormentas del invierno. El 21 de marzo de 1616 partieron, y tras cruzar el Canal de la Mancha, una tormenta dispersó la escuadra y daño seriamente el galeón del almirante Brochero, el cual no tuvo más remedio que dirigirlo hacia la costa inglesa, arribando al puerto de Plymouth el 31 de marzo. ${ }^{94}$ Desde allí el almirante se dirigió a Londres a reunirse con el embajador Gondomar y solicitar ayuda para reparar el navío y socorrer a la tripulación, ochenta y una personas entre oficiales, soldados, religiosos y tripulantes. Por su parte, Gondomar envió a un hombre suyo a Plymouth a supervisar las reparaciones, en que se gastaron 9.317 reales (unos 847 ducados). ${ }^{95}$

Así termina el breve informe. De acuerdo con el mismo, nada especialmente negativo ocurrió en el puerto de Plymouth contra el galeón o su tripulación, ya que de haber ocurrido, Brochero lo hubiera consignado en su informe al embajador. De hecho, a partir de la paz de agosto de 1604, este era uno de los objetivos de la Monarquía: convertir las costas y puertos británicos en lugar de refugio y reabastecimiento de sus armadas en el Canal de la Mancha y el Mar del Norte frente a Francia y especialmente Holanda. Las razones de ello pudieran ser, entre otras, la existencia de una atmosfera política más calmada en Inglaterra en el

91 El propio tratado de paz de agosto de 1604 entre la Monarquía Hispánica e Inglaterra, o la misma Tregua de los Doce Años de 1609 ya establecía la posibilidad de que navíos de ambos estados tomaran refugio en sus puertos por causa de las tormentas.

92 Las tormentas solían hundir, dispersar o desviar a los barcos de su ruta, o forzarlos a tomar refugio en las costas británicas; también eran un factor a tener en cuenta en la guerra naval entre la Monarquía y Holanda; algunos ejemplos en la documentación, véase AGS, Estado, 8791, 44. Don Carlos Coloma a Su Majestad. Londres 4 de junio de 1623; Estado, 841, 29. Condestable de Castilla a Su Majestad. Bergas, 23 de mayo de 1604; BNM, ms. 9133, 63-74. Fray Diego de la Fuente al conde de Gondomar. Londres, 20 de octubre de 1618; CSP, Venice, (1603-1607). Nicolo Molin, embajador veneciano en Inglaterra, al Dogo y Senado. Londres 22 de diciembre de 1605.

${ }_{93}$ El galeón perdido se llamaba San Luís y era la nave capitana de la escuadra.

94 El galeón, de nombre San Alberto, iba cargado además con los cañones del navío perdido; según el informe, se abrió la popa con lo que empezó a inundarse el navío, se rompió la vela y verga del trinquete, la vela mayor, algunas jarcias y la estopa del casco empezó a desprenderse.

95 Este hombre era el portugués Antonio da Costa D'oliveira, y era un comerciante que había trabajado prestando dinero al embajador: BNM, ms. 18419, 87. Don Diego Sarmiento de Acuña a Pedro Garcia Dovalle. Londres 20 de noviembre de 1614; BP, II/2185, 56. Relación del dinero que por orden de Su Majestad ha recibido don Diego Sarmiento de Acuña, conde de Gondomar, para gastos de la embajada de Inglaterra y de lo que tiene gastado en su servicio desde fin del mes de diciembre de 1615 (que envió sus cuentas anteriores) a fin del mes de diciembre de 1617 que se cumplen 2 años. Londres 31 de diciembre de 1617. 
marco de un periodo de relativa paz en el norte de Europa entre la Monarquía, Inglaterra, Francia y Holanda. ${ }^{96}$

Muy diferente será la situación que reflejan los siguientes documentos. Elaborados entre los años 1623 y 1626, son mucho más detallados que el elaborado por el almirante Brochero en 1616. Además, están interrelacionados entre sí. Uno es el informe de un sargento de infantería a bordo de un galeón flamenco refugiado en un puerto de Escocia. ${ }^{97} \mathrm{EI}$ otro, una hoja de servicios de un mercader escocés católico que tuvo un papel protagonista en la ayuda a ese mismo galeón. Ambos testimonios no se pueden entender sin la actuación de la embajada española en Inglaterra, amparando a los navíos de guerra hispánicos que llegaban a las costas británicas y protegiendo a todos aquellos que servían a la Monarquía.

A partir de abril de 1621 la finalización de la Tregua de los Doce Años con los holandeses y el ascenso al trono de Felipe IV (junto con don Baltasar de Zúñiga y su sobrino el conde-duque de Olivares al gobierno de la Monarquía) vendrían de la mano. La Monarquía, ya interviniente en la Guerra de los Treinta Años apoyando al emperador (desde 1618), se disponía a desencadenar una gran tormenta sobre Holanda, apoyada esta vez en una guerra total por mar contando con los puertos flamencos y la neutralidad británica. Sin embargo, ambos documentos reflejan la debilidad de la posición española en Inglaterra en los decisivos años 1621-1625, poniendo en evidencia las dudas y vacilaciones del gobierno inglés, y específicamente del rey (Jacobo I Estuardo) y del príncipe de Gales (su heredero, Carlos Estuardo), que se veían sometidos a las fuertes presiones desestabilizadoras de un triángulo con tres vértices situados fuera de Inglaterra. Uno en Holanda (antiguo aliado de Inglaterra contra Felipe II, país de fe protestante, con una gran relación económica y comercial con los ingleses), otro en Alemania (el líder de los protestantes en lucha contra el emperador era Federico del Palatinado, yerno de Jacobo) y el último en España (en los años 1621-1623 se estaba en la fase más importante de las negociaciones matrimoniales para unir al príncipe de Gales con la infanta María, hija de Felipe III, en las cuales los Austrias españoles exigían el apoyo inglés contra los holandeses). ${ }^{98}$

A ello había que sumar la hostilidad de una gran parte de la población británica, que consideraba la alianza matrimonial anglo-española casi contra natura, por lo que muchas veces miraba con simpatía la alternativa de Federico del Palatinado y su esposa María Estuardo como sucesores de

96 Paces de 1598 con Francia, 1604 con Inglaterra y Tregua de 1609 con Holanda.

97 Este episodio fue señalado brevemente por Alcalá-Zamora y Queipo de Llano, J. 1975. España, Flandes y el Mar del Norte; Stradling, R.A. 1992. La Armada de Flandes y por Worthington, D. 2004. Scots in Habsburgh Service, 1618-1648. Leiden.

98 Sobre la política exterior de Jacobo Estuardo con relación a España, ver Adams, S.1983. "Spain or Netherlands? The Dilemmas of Early Stuart Foreign Policy" en H. TOMLINSON (ed.). Before the English civil War: 79-101. London: Macmillan; y también Parker, G. 2004(ed.) La guerra de los Treinta Años; con respecto a las negociaciones matrimoniales con España, Samson, A. (ed.) 2006. The Spanish Match. Prince Charles's journey to Madrid, 1623, Aldershot; Cogswell, Th. 1989. "England and the Spanish match", en R. Cust \& A. Hugues (eds.), Conflict in Early Stuart England, Studies in religion and politics 16031642: 107-133. London \& New York; y Redworth, G. 2004. El príncipe y la Infanta. Una boda real frustrada, Madrid.
Jacobo I en lugar del príncipe de Gales, juzgado próximo a la Monarquía Hispánica y al catolicismo. ${ }^{99}$

El informe es obra de un soldado español, el sargento Juan de Sagastizabal, cabo de infantería sirviendo en el galeón San Ambrosio. ${ }^{100}$ Tras el incendio del navío, escribió una relación del suceso y marchó a Londres con otros tres soldados, donde fueron ayudados por el embajador don Carlos Coloma para continuar su viaje hasta Dunkerque, uno de los principales puertos flamencos bajo dominio hispánico. ${ }^{101} \mathrm{El}$ informe de Sagastizabal es importante porque es un relato en primera persona de lo ocurrido en uno de esos combates en aguas británicas, un testimonio directo de los padecimientos y trabajos que los soldados y tripulaciones de la Monarquía tuvieron que soportar en territorios teóricamente neutrales como eran los británicos, pero donde eran odiados con la misma intensidad que lo eran por los holandeses. La narración cuenta las repetidas negativas del consejo de Escocia para proteger el galeón, que quedó varado en la boca del puerto cuando intentó salir de Leith y a merced de los disparos de los navíos holandeses que esperaban fuera. ${ }^{102}$ Es más, al desembarcar la tripulación del navío, fue asaltada y maltratada por las gentes de la villa, que incluso se aventuraron al galeón varado a saquearlo, y todo esto sin que las autoridades lo impidieran. Lo único que consiguieron los oficiales del navío fue ponerlo bajo la protección de Jacobo (con sus estandartes) y permitir desembarcar la artillería, que luego se apropiaron los escoceses: "ya no era nuestra artillería porque pertenecía de derecho al Serenísimo Rey de Gran Bretaña". ${ }^{103}$ Finalmente, los holandeses, la media noche del 16 de mayo, quemaron el galeón con tres barriles de pólvora, gota que rebosaba el vaso de las vejaciones sufridas por los españoles. Sagastizabal lo resumió muy acertadamente:

"desde el primer día han llevado intento estos señores escoceses de destruirnos y perdernos, no me espanto sino de lo que lo hayan dilatado tanto y hasta para dar cuenta a

99 Entre 1618 y 1623 la pareja formada por Federico del Palatinado y su esposa Isabel Estuardo fueron elevados por parte de la población inglesa más hostil al catolicismo y la alianza con España como los candidatos ideales al trono tras la muerte de Jacobo: BP, II/551, 202-203. Fray Diego de la Fuente a Su Majestad. Londres, 29 de agosto de 1619; II/2108, 103. Conde de Gondomar a la infanta Isabel Clara Eugenia. Londres, 1 de enero de 1622; BNM, ms. 18434, 72-76. Voto en el consejo de Estado del marqués de Montesclaros sobre la liga con el Emperador y duque de Baviera. 29 de mayo de 1625; Cogswell,TH. 1989. The blessed revolution: English politics and the coming of war, 1621-1624: 95 y ss. Cambridge \& New York.

$100 \mathrm{BP}, \mathrm{II} / 2198,79$. Relación que hace Juan de Sagastizabal, cabo de la infantería que servía a Su Majestad en el galeón San Ambrosio, quemado por los holandeses dentro del puerto de Lith en el reino de Escocia a 16 de mayo de 1623. Edimburgo, 17 de mayo de 1623.

101 El galeón fue quemado el 16 de mayo, el informe tiene fecha de 17; la relación fue enviada por Coloma a Flandes y a España a finales de mayo (días 22 y 25); el 8 de junio, en Londres, Coloma pagó 310 reales a Sagastizabal y otros tres soldados como adelanto de sus sueldos para continuar viaje: AGS, Estado, 8791, 31. Don Carlos Coloma a Juan Ciriza. Londres, 22 de mayo de 1623; 8782, 19. Marqués de los Balbases a don Carlos Coloma. Bruselas, 7 de junio de 1623.

102 Los disparos de la artillería holandesa alcanzaron a la villa de Leith, matando a dos niños y a un hombre.

103 BP, II/2198, 79. Relación que hace Juan de Sagastizabal, cabo de la infantería que servía a Su Majestad en el galeón San Ambrosio, quemado por los holandeses dentro del puerto de Lith en el reino de Escocia a 16 de mayo de 1623. Edimburgo, 17 de mayo de 1623. 
Vuestra Excelencia desta gracia no nos querían el Canciller [George Hay, conde de Kinnoull] ni el consejo [de Escocia] dejar tomar caballos. Finalmente señor, si escribiéramos en guerra con este reino [de Escocia], no nos pudieran haber hecho mayores extorsiones y agravios". ${ }^{104}$

Como mostraban los informes de un espía inglés de la embajada española, la quema del galeón flamenco en Leith obligó al rey Jacobo a abandonar su neutralidad (a su pesar) y enviar dos navíos reales a escoltar el que permanecía refugiado en Aberdeen. ${ }^{105}$ Quemar un navío bajo su protección y dentro de un puerto de sus dominios era una provocación demasiado grande para no hacer nada. De esta forma, Jacobo se arriesgaba a un enfrentamiento armado entre sus navíos y los holandeses, cosa que finalmente ocurrió:

"los holandeses están muy irritados aunque como son cuerdos disimularan y al fin ingleses no han hecho más que vengar el atrevimiento de haber quemado el galeón español en Leith, y lo harán también por dar gusto a estos españoles que no se cansan de procurar que estas dos naciones tan provechosamente amigas vengan a las manos". 106

El incidente animó al embajador Coloma a escribir que

"no querría tener otros enemigos sino los holandeses y creo muy de veras que para acabar con ellos no hay otro camino que estrecharnos del todo con este Rey, y obligarle, ya que habémosle dado nuestra Infanta, a que haga milagros, como los comenzamos a ver habiendo peleado dos galeones suyos con cinco...de Holanda por defender al nuestro...de que ha resultado haber querido matar en Flesinguen a todos los ingleses que se hallan allí". ${ }^{107}$

El informe de Sagastizabal precisamente difiere del que realizó don Diego Brochero por la hostilidad que describe en la población local, así como por la pasividad de las autoridades escocesas por hacer cumplir las órdenes reales de asegurar la neutralidad de las aguas bajo soberanía del rey Jacobo I. Hay que considerar que sobre cada episodio concreto de combates entre navíos hispánicos y holandeses en puertos y costas británicas se superponían varios elementos.

En primer lugar, hay que considerar que Escocia era un reino aparte de Inglaterra, en donde habían triunfado las doctrinas de Juan Calvino (Presbiterianismo, aprobado por el parlamento escocés en 1560). El calvinismo era la rama de las iglesias protestantes más alejada del catolicismo (en cuanto a doctrina, práctica y organización), así como la más agresiva y militante frente a la Iglesia Católica. Tenía una fuerza espiritual, doctrinal y una voluntad de proselitismo similar al Papado, y si la Iglesia tenía su Roma, el

\footnotetext{
104 Ídem.

105 BP, II/2198, 82-83. Avisos del Incognito. Londres, 4 de junio de 1623.

106 Ibídem, II/2200, 34-35. Avisos del Incognito. Londres, 24 de agosto, 1 y 8 de septiembre de 1623 .

107 Sir William Semple y sir Anthony Sherley, oficiales católicos británicos al servicio de España, también subrayaron la importancia de los puertos ingleses para la Monarquía: AGS, Estado, 8792, 15. Don Carlos Coloma al cardenal de la Cueva. Londres, 25 de agosto de 1623; BNM, ms. 10794, 151-200. Discurso excelentísimo de la conveniencia de los casamientos del príncipe de Inglaterra con la señora Infanta de España. 1619. Sir Anthony Sherley; ms. 2354, 224-225. Sobre Inglaterra y las condiciones para los casamientos entre el Príncipe de Gales y la Infanta María. William Semple. Madrid, 18 de julio de 1623.
}

calvinismo organizaba su expansión desde Ginebra. Allí donde creció, fue una de las razones de sangrientos conflictos con el catolicismo desde 1559 hasta 1648 (Francia y las guerras de Religión, los Países Bajos y la guerra de Flandes, Centroeuropa y la guerra de los Treinta Años).

Además de ello, las circunstancias que llevaron a la implantación del calvinismo en Escocia fueron particularmente turbulentas, con una guerra abierta entre la regente María de Guisa, apoyada por tropas francesas desde 1548, frente a una alianza de John Knox y la nobleza escocesa con apoyo inglés. Este conflicto, cuyo momento álgido fue el asedio del puerto de Leith (1559-1560), donde estaban fortificados los franceses, terminó con el llamado tratado de Edimburgo o Leith (julio de 1560). ${ }^{108}$ Este tratado aseguraba la retirada francesa, la consolidación del protestantismo escocés y la garantía para Inglaterra de una Escocia no católica y libre de la influencia francesa.

No es difícil ver el papel simbólico que Leith tenía para los escoceses, como lugar de triunfo del Presbiterianismo sobre los poderes extranjeros católicos (Papado, Francia, Monarquía Hispánica). Sagastizabal, su navío y sus hombres parecían estar pagando, en los años 1622-1623, la factura de odio que los soldados franceses católicos habían dejado pendiente 70 años antes.

Por otro lado, estaba la situación internacional. En 1617, don Diego Brochero había llegado al puerto de Plymouth y no informó de especiales conflictos. La situación en el norte de Europa era por entonces de calma, tras los grandes tratados de 1598, 1604 y 1609. Lo cierto es que la población protestante británica reaccionaba con mayor hostilidad contra el catolicismo, el Papado y la Monarquía Hispánica cuando se daban acontecimientos internacionales que enfrentaban a católicos y protestantes. Episodios de furia anti-española y anti-católica en Inglaterra ocurrieron en los años 1605-1606 (conspiración de la Pólvora y el complot de Neuce y Franchesi), 1618-1621 (guerra de los Treinta Años y Palatinado) y 1623-1625 (rechazo del tratado matrimonial y del Palatinado).

Por último, hay que subrayar la inacción de las autoridades escocesas frente a las órdenes de Jacobo I. Los motivos podrían ser diversos. El odio a lo español, compartido con la población local. La presión y sobornos repartidos por los holandeses, que también estaban allí y tenían a sus navíos en Leith y Abeerden, ejerciendo una temible presencia. La lejanía del rey Jacobo y la corte, desde la ida de los Estuardo a Londres como capital del reino principal de Gran Bretaña. La divergencia entre los intereses de la política internacional jacobita para Inglaterra (alianza con España, árbitro de Europa, no beligerancia religiosa, acceso a la plata española vía comercio inglés) frente a los de Escocia, reino más alejado de los problemas y conflictos de la Europa del Barroco. ${ }^{109}$ Todo ello podría asimilarse a la célebre formula

108 Durante el asedio, entre los meses de marzo y mayo de 1560, hubo numerosos combates alrededor de Leith entre las tropas francesas y los ingleses y escoceses: Glasgow, Linlithgow, Pelham, Mount Somerset, Mount Falcon y Byer's Mount; sobre los combates, ver Chalmers, G. 1817. Churchyard's Chips Concerning Scotland: 88 y ss: R \& A Taylor; Campbell, A. 1827. The history of Leith, from the earliest accounts to the present period: 55 y ss: William Reid \& Son.

109 Para ver más sobre estos conflictos, Haigh, C. 1993. English Reformations. Religion, Politics and Society under the Tudors. Oxford, Oxford Univesity Press; Lockyer, R. 1999. The Early Stuarts: A political 
del derecho castellano de la Baja Edad Media, obedézcase pero no se cumpla. Estos pequeños indicios de disensiones de nobleza y obispos de Escocia frente a la autoridad real de los Estuardo, que era una dinastía escocesa, continuaban la violencia que había existido alrededor del trono escocés durante la minoría de Jacobo, y luego posteriormente con las dos guerras de los Obispos en tiempos de Carlos I Estuardo (1638-1640). ${ }^{110}$

Para complementar el informe del sargento Sagastizabal, existe el memorial de servicios prestados a la Corona española por parte del comerciante católico escocés William Laing. ${ }^{111}$ En este informe se cuenta que Laing fue nombrado por el embajador Coloma Agente en Escocia el 10 de octubre de 1622 (todo con la aprobación del rey Jacobo), que el 19 de abril de 1623 le fue concedido un entretenimiento a pagar por la embajada de Inglaterra de 40 escudos mensuales y que finalmente fueron declarados el 22 de junio de 1624 él, su mujer y Thomas Laing (¿su hermano?)

"al son de trompeta por rebeldes al dicho rey [de Inglaterra], mandándoles confiscar sus bienes por profesar y defender la fe católica y bautizar a sus hijos de manos de sacerdotes católicos, a quienes contra las leyes de aquel reino recibían y sustentaban en sus casas lo cual parece haberse ejecutado así el 7 de agosto de 1624 en la ciudad de Aberdeen, de donde son naturales los contenidos". ${ }^{112}$

Laing tuvo un papel fundamental en el rescate de los galeones flamencos refugiados en los puertos de Leith y Aberdeen en los años 1622-1623. Es lógico pensar que los oficiales de los galeones quisieran obtener abastecimientos, provisiones y pólvora para mantener a tripulaciones y navíos, por lo que encontrar a un leal comerciante escocés católico, conocedor del lugar, y bien dispuesto para hacerlo era la mejor opción. La declaración del sargento Sagastizabal muestra que Laing fue probablemente el único mercader en ofrecerse a abastecer a los navíos. Sus motivaciones, aparte del beneficio comercial, parecen ser religiosas (era católico en un territorio fervientemente presbiteriano como Escocia y además formaba parte de esa pequeña minoría católica que protegía a sacerdotes y jesuitas en Gran Bretaña), lo que facilitó el contacto con los oficiales de los galeones flamencos. El caso de Laing parecía ser, al fin y al cabo, uno de los frutos del apoyo español al mantenimiento del catolicismo en Gran Bretaña, bien a través de la embajada, bien desde los diversos seminarios católicos para británicos en España y Flandes que enviaban a misioneros y clérigos de forma constante y en secreto. ${ }^{113}$

History of England 1603-1642: Harlow, Essex, Longman; Sommerville, J.P.1999. Royalists \& Patriots: Politics and Ideology in England 16031640: Harlow, Essex, Pearson.

110 Ver Fissel, M. Ch. 1994. The Bishops' Wars: Charles I's Campaigns Against Scotland, 1638-1640: Cambridge, Cambridge University Press.

111 AHN, Estado, 800, s/f. Hoja de servicios del comerciante católico escocés William Laing.

112 Ídem.

113 Los embajadores españoles ayudaban constantemente a miembros del clero católico a dirigirse en misiones por toda Inglaterra, Irlanda y Escocia; en 1620 el conde de Gondomar financió la misión católica en Escocia con 10.000 reales, Coloma pagaría 988 reales a diversos sacerdotes y monjes de camino a sus misiones entre 1622 y 1624 para ver más sobre el catolicismo en la Inglaterra isabelina y de los Estuardo, consultar A. J. Loomie, A. Fraser, La Conspiración de la Pólvora.
En una Gran Bretaña neutral, una minoría católica fuerte, unificada, bien identificada y apoyada era esencial para la Monarquía Hispánica. Los frutos de ello, al margen de la conservación en sí de la fe católica en reinos protestantes, era la disponibilidad de una parte de la población favorable a los intereses españoles, basándose en el principio de que allí donde hubiera un católico, habría un aliado. ${ }^{114}$ No sólo se trataba de que la Monarquía reclutara soldados y oficiales para sus ejércitos, artilleros, pilotos y tripulaciones para sus armadas o espías y confidentes para sus servicios de información en el Norte de Europa. También servía para casos como los mencionados, cuando servidores de la Monarquía acababan en Gran Bretaña y podían contar con algún tipo de apoyo, dada la hostilidad de la población protestante en general.

Todo ello tampoco sería ajeno las buenas relaciones que mantenían por entonces Inglaterra y la Monarquía Hispánica (precisamente entre junio de 1622 y septiembre de 1623 fueron los meses de mayor acercamiento entre ambos estados, cuando el príncipe de Gales viajó a España a negociar su matrimonio con la infanta española doña María, hermana del rey Felipe IV), lo que propició un ambiente (provisional) de mayor tolerancia oficial hacia el catolicismo. ${ }^{115}$ Quizá Laing viera también la oportunidad de optar a alguna merced por Felipe IV (como de hecho consiguió), aunque cuesta más imaginarse que todos sus esfuerzos se produjeran simplemente por la esperanza de una gran recompensa. ${ }^{116}$ De ser así, desde luego no mereció la pena. Perdió sus negocios como comerciante en Escocia al quedar marcado como católico y colaboracionista del poder español, fue encarcelado por un tiempo en Edimburgo, los holandeses pusieron precio a su cabeza y finalmente su propio soberano (Jacobo) le condenó a él y a su familia como rebeldes, confiscándoles sus bienes en Aberdeen, por lo que los Laing tuvieron que tomar el camino del exilio a Flandes, bajo la protección de la Corona española.

Catolicismo y Terror en la Europa del siglo XVII; o J. Burrieza Sánchez, Una Isla de Inglaterra en Castilla, Palencia, 2000; Escuela de sacerdotes y mártires: los Colegios del exilio católico. en Irlanda y la Monarquía Hispánica: Kinsale 1601-2001: guerra, política, exilio y religión.

114 En 1624 el conde de Gondomar destacaba la importancia de los católicos ingleses para la Monarquía ya que los que no entran en religión lo hacen en milicia [de Vuestra Majestad] y los parientes que quedan en Inglaterra son para inteligencias (tener personas de secreto, dar avisos ciertos y seguros sin espías, para poder echar al ejército en tierra inglesa, que sepa caminos, puertos de mar y otras cosas). Se mantiene receloso al rey respecto de sus vasallos y se evita que sus reinos (irreconciliables) se unan a pesar suyo con su rey; AGS, Estado, 2516, 83 (consulta de Estado, julio de 1624).

115 El embajador Coloma informaba en los años 1622-1623 del favorable ambiente para el catolicismo que existía en Inglaterra: AGS, Estado, 8788, 6 (mayo de 1622); 8789, 58,59 (febrero de 1623); 8790, 43 (abril de 1623); para ver más sobre la situación de "rehenes" de los católicos británicos en medio de las negociaciones hispano-inglesas de los años 1622-1623, véase Redworth, G. 2004.

116 Su nombramiento como Agente en Escocia de Felipe IV se veía recompensado por 40 escudos al mes a cargo de la embajada, unas diez libras esterlinas; el cargo no conllevaba ningún privilegio de carácter diplomático, sino simplemente hacía de representante de Felipe IV en Escocia, a sueldo directo y obediencia del embajador español en Inglaterra; de hecho, sufrió cárcel, confiscación y exilio: AGS, Estado, 2516, 4. Consulta de oficio del consejo de estado sobre una carta de don Carlos Coloma acerca del socorro de dos galeones en Escocia. Madrid 17 de febrero 1623. 


\section{CONCLUSIONES}

Los escritos del almirante don Diego Brochero, del soldado Sagastizabal y del mercader William Laing ofrecen una visión clara y concisa del papel que la Inglaterra de Jacobo I Estuardo jugaba en medio de la guerra naval que sostenían la Monarquía Hispánica y las Provincias Unidas en el primer cuarto del siglo XVII. Si bien en un reino neutral, la posición española en Gran Bretaña se revelaba frágil a los ojos de aquellos que luchaban en primera línea contra los enemigos de la Monarquía, contradicciones propias del ejercicio de la diplomacia europea de los siglos XVI-XVII, donde los conflictos políticos y las rivalidades económicas se mezclaban con los enfrentamientos religiosos entre protestantes y católicos. Las lealtades políticas muchas veces divergían de las religiosas, lo que provocaba y aumentaba la confusión tan propia del mundo Barroco. William Laing es un buen ejemplo de todo ello. Católico entre protestantes, súbdito escocés luego servidor de España, mercader convertido en diplomático, lo que en los años 1622-1623 aprobaba su señor y rey natural, por motivos diplomáticos y políticos lo convertiría en un traidor en 1624 (cuando el fracaso de las negociaciones matrimoniales anglo españolas de 1623 perjudicó muy notablemente las relaciones entre Inglaterra y España). El episodio de los galeones flamencos refugiados en Escocia sería uno más de los ocurridos en esos años de no ser por Sagastizabal y Laing. De hecho, lo que lo ha descubierto para la Historia es que, a diferencia de los episodios de 1605 o 1624 ocurridos en Dover, donde hubo similares quejas por parte de soldados y oficiales por la falta de provisiones, problemas de convivencia con la población local y desidia de las autoridades británicas, ni el maestre de campo don Pedro de Sarmiento ni don Diego Luis de Oliveira encontraron a ningún William Laing que se ofreciera a ayudar a sus hombres y galeones. Por ello, los historiadores también debemos estar agradecidos, cuatro siglos después, a aquel mercader escocés.

\section{ARCHIVOS}

- Archivo Casa Ducal de Alba (Madrid).

- Archivo General de Simancas (Simancas).

- Archivo Histórico Nacional (Madrid).

- Biblioteca Nacional (Madrid).

- British Library (Londres).

- Biblioteca de Palacio Real (Madrid).

\section{BiBLIOGRAFÍA}

Adams, S. 1983. "Spain or Netherlands? The Dilemmas of Early Stuart Foreign Policy", en H. Tomlinson (ed.), Before the English civil War: 79-101. London: Macmillan.

Alcalá-Zamora y Queipo de Llano, J. 1975. España, Flandes y el mar del Norte (1618-1639). La última ofensiva europea de los Austrias madrileños. Barcelona: Centros de Estudios Constitucionales.

Allen, P.C. 2001. Felipe III y la Pax Hispánica. Madrid: Alianza.

Alloza Aparicio, A. 2006. Europa en el mercado español. Mercaderes, represalias y contrabando en el siglo XVII, Salamanca: Junta de Castilla y León.

Brightwell, P. 1974. "The Spanish system and the twelve years's truce". English Historical Review: 270-292.

Burrieza Sánchez, J. 2000. Una isla de Inglaterra en Castilla. Palencia.

- 2002. "Escuela de sacerdotes y mártires: los Colegios del exilio católico", en Enrique García Hernán (ed). Irlanda y la Monarquía
Hispánica: Kinsale 1601-2001: guerra, política, exilio y religión: 39-74. Madrid: CSIC.

Campbell, A. 1827. The history of Leith from the earliest accounts to the present period: with a sketch of the antiquities of the town. Leith: William Reid\& Son.

Carnicer, C. y Marcos, J. 2005. Espías de Felipe II. Los servicios secretos del Imperio español, Madrid: La Esfera de los Libros.

Cogswell, Th. 1989. "England and the Spanish match", en Richard Cust \& Ann Hugues (eds.), Conflict in Early Stuart England, Studies in religion and politics 1603-1642: 107-133. London \& New York: Longman.

- 1989. The blessed revolution: English politics and the coming of war, 1621-1624. Cambridge \& New York: Cambridge University Press.

Chalmers, G. 1817.Churchyard's chips concerning Scotland. London: R\&A Taylor.

Elliot, J.H. 1998. El conde-duque de Olivares. El político en una época de decadencia. Barcelona: Mondadori.

Fernández Duro, C. 1895-1903. Historia de la Armada Española (desde la unión de los reinos de Castilla y Aragón). Madrid: Sucesores de Rivadeneyra.

Feros, A. 2002. El duque de Lerma. Realeza y privanza en la España de Felipe III, Madrid: Marcial Pons.

Fraser, A. 2004. La Conspiración de la Pólvora. Catolicismo y Terror en la Europa del siglo XVII. Madrid: Turner Publicaciones.

García García, B. 1996. La Pax Hispánica. Política exterior del duque de Lerma, Leuven: Leuven University Press.

- 2008, "Peace with England, from Convenience to Necessity, 15961604", en A. J. Cruz (ed.), Material and Symbolic Circulation between Spain and England, 1554-1604: 135-150. Hampshire: Ashgate.

Gelabert, Juan E. 2008. "Guerra y coyuntura fiscal: el embargo general de 1598". IX Congreso de la Asociación española de Historia Económica, Murcia.

Gómez-Centurión, C. 1988. Felipe II, la empresa de Inglaterra y el comercio septentrional (1566-1609). Madrid: Editorial Naval.

Goodman, D. 2001. El poderío naval español. Historia de la armada española del siglo XVII, Barcelona: Península.

Guell Junkert, M. 2004. "Diego Brochero, el lobo de mar salmantino". Revista de Historia Naval, 87: 95-104.

Haigh, C. 1993. English Reformations. Religion, Politics and Society under the Tudors, Oxford, Oxford Univesity Press.

Israel, J.I. 1990. Empires and entrepots: the Dutch, the Spanish monarchy and the Jews, 1585-1713, London: Bloomsbury Academic.

--1995. The Dutch republic. Its rise, greatness and fall 1477-1806, Oxford: Oxford University Press.

Kingsbury, B. 2000. "Gentili, Grotius and the extra-european world", en H.N. Scheiber (ed.), The Law of the Sea: 39-60. The Hague.

Lockyer, R. 1999, The Early Stuarts: A political History of England 16031642. Harlow, Essex: Longman.

Loomie, A.J. 1996. Spain and the Early Stuarts, 1585-1655, Aldershot: Ashgate Variorum.

Parker, G. 2000. El ejército de Flandes y el Camino Español, 1567-1659. Madrid: Alianza Editorial.

- 1986. España y los Países Bajos 1559-1659. Madrid: Ediciones Rialp.

- 1998. La gran estrategia de Felipe II. Madrid: Alianza Editorial.

- 2003. La Guerra de los Treinta Años, Madrid: Antonio Machado.

-1976. La revolución militar. Innovación militar y apogeo en occidente, 1500-1800, Madrid: Editorial Alianza.

Pi Corrales, M. 1983. La otra invencible. 1574. España y las potencias nórdicas. Madrid: San Martín.

Rahn Phillips, C. 1991. Seis galeones para el rey de España. La defensa imperial a principios del siglo XVII, Madrid: Alianza Editorial.

Redworth, G. 2004. El príncipe y la infanta. Una boda real frustrada. Madrid: Editorial Taurus.

Sabek, B. y Deng, S. 2008. Global traffic: discourses and practices of trade in English literature and culture from 1550 to 1700. New York: Palgrave Macmillan.

Samson, A (ed.) 2006. The Spanish Match. Prince Charles's journey to Madrid, 1623. Ashgate Publishing.

Sanz Camañes, P. 2002. Diplomacia hispano-inglesa en el siglo XVII. Razón de Estado y Relaciones de Poder durante la Guerra de los Treinta años, 1618-1648, Cuenca: Ediciones de la Universidad de Castilla La Mancha. 
- 2012. Los ecos de la Armada. España, Inglaterra y la estabilidad del Norte (1585-1660). Madrid: Silex.

Sommerville, J.P. 1999. Royalists \& Patriots: Politics and Ideology in England 1603-1640. Harlow, Essex: Pearson.

Stradling, R.A. 1983. Europa y el declive de la estructura imperial española 1580-1720, Madrid: Cátedra.

- 1989. Felipe IV y el gobierno de España, 1621-1665, Madrid: Alianza Editorial.

- 1992. La armada de Flandes. Política naval española y guerra europea, 1568-1668, Madrid: Alianza Editorial.

Thompson, I.A.A. 1981. Guerra y decadencia. Gobierno y administración en la España de los Austrias (1560-1620), Barcelona: Crítica.
- 2004. "La guerra y el soldado", en Antonio Feros y Juan Gelabert (eds.), España en tiempos del Quijote: Madrid: Tarus.

- 2005. "Sir Charles Cornwallis y su Discurso sobre el Estado de España (1608)", en Porfirio Sanz Camañes (ed.), La Monarquía Hispánica en Tiempos del Quijote: 65-101. Madrid.

Van der Molen, G. 1968. Alberico Gentili and the Development of International Law. Leiden: A. W. Sijthoff.

Williams, P. 2001. "Don Diego de Brochero de Paz y Anaya (c. 1535-1625). Corsario, almirante y administrador". Cuadernos Monográficos del Instituto de Historia y Cultura Naval 37: 7-14.

Worthington, D. 2004. Scots in Habsburgh Service, 1618-1648, Leiden: Brill. 